Prepared in cooperation with the South Platte Natural Resources District, Conservation and Survey Division of the University of Nebraska-Lincoln, and the Nebraska Environmental Trust

\title{
Hydrostratigraphic Interpretation of Test-Hole and Borehole Geophysical Data, Kimball, Cheyenne, and Deuel Counties, Nebraska, 2011-12
}

Open-File Report 2014-1103 



\section{Hydrostratigraphic Interpretation of Test- Hole and Borehole Geophysical Data, Kimball, Cheyenne, and Deuel Counties, Nebraska, 2011-12}

By Christopher M. Hobza and Steven S. Sibray

Prepared in cooperation with the South Platte Natural Resources District, Conservation and Survey Division of the University of Nebraska-Lincoln, and the Nebraska Environmental Trust

Open-File Report 2014-1103 


\title{
U.S. Department of the Interior SALLY JEWELL, Secretary
}

\section{U.S. Geological Survey \\ Suzette M. Kimball, Acting Director}

\author{
U.S. Geological Survey, Reston, Virginia: 2014
}

For more information on the USGS - the Federal source for science about the Earth, its natural and living resources, natural hazards, and the environment, visit http://www.usgs.gov or call 1-888-ASK-USGS.

For an overview of USGS information products, including maps, imagery, and publications, visit http://www.usgs.gov/pubprod

To order this and other USGS information products, visit http://store.usgs.gov

Any use of trade, firm, or product names is for descriptive purposes only and does not imply endorsement by the U.S. Government.

Although this information product, for the most part, is in the public domain, it also may contain copyrighted materials as noted in the text. Permission to reproduce copyrighted items must be secured from the copyright owner.

Suggested citation:

Hobza, C.M., and Sibray, S.S., 2014, Hydrostratigraphic interpretation of test-hole and borehole geophysical data, Kimball, Cheyenne, and Deuel Counties, Nebraska, 2011-12: U.S. Geological Survey Open-File Report 2014-1103, 45 p., http://dx.doi.org/10.3133/ofr20141103/.

ISSN 2331-1258 (online) 


\section{Contents}

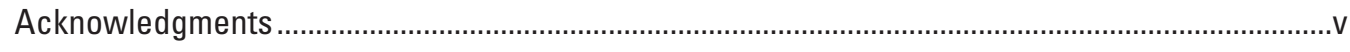

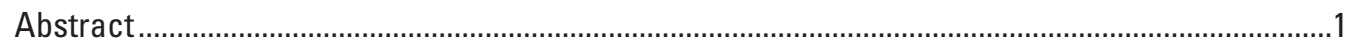

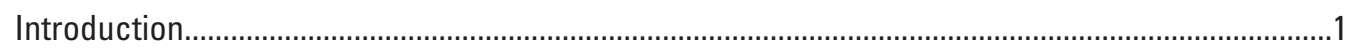

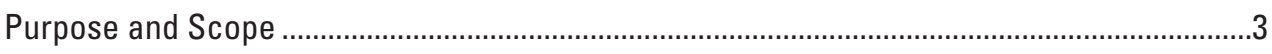

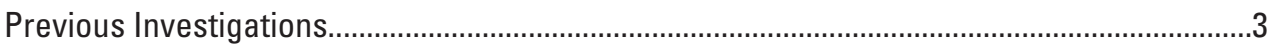

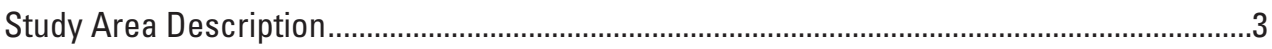

Geologic Setting and Hydrogeology .....................................................................................

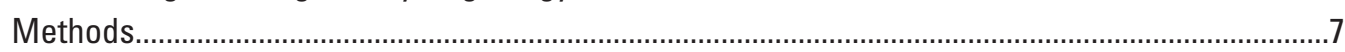

Test-Hole Drilling and Borehole Geophysics .............................................................................

Test-Hole Drilling Method and Procedure .........................................................................

Borehole Geophysical Data Collection ...........................................................................

Global Positioning System Survey ............................................................................................10

Hydrostratigraphic Interpretation of Test-Hole and Borehole Geophysical Data .........................10

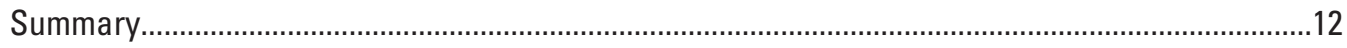

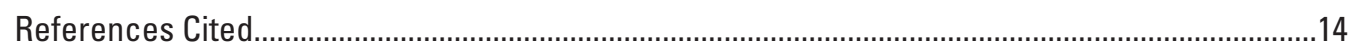

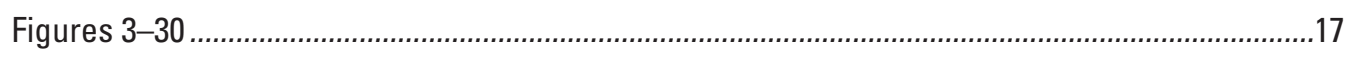

\section{Figures}

1. Map showing location of the study area and drilled test holes, Kimball, Cheyenne, and Deuel Counties, Nebraska, 2011-12.

2. Graph showing composite of generalized lithologic description and geophysical logs for test hole 1-SP-11, Kimball County, Nebraska.

3. Graph showing composite of generalized lithologic description and geophysical logs for test hole 2-SP-11, Kimball County, Nebraska.

4. Graph showing composite of generalized lithologic description and geophysical logs for test hole 3-SP-11, Kimball County, Nebraska.

5. Graph showing composite of generalized lithologic description and geophysical logs for test hole 4-SP-11, Kimball County, Nebraska.

6. Graph showing composite of generalized lithologic description and geophysical logs for test hole 5-SP-11, Kimball County, Nebraska..............................................................21

7. Graph showing composite of generalized lithologic description and geophysical logs for test hole 6-SP-11, Kimball County, Nebraska.

8. Graph showing composite of generalized lithologic description and geophysical logs for test hole 7-SP-11, Kimball County, Nebraska.

9. Graph showing composite of generalized lithologic description and geophysical logs for test hole 8-SP-11, Kimball County, Nebraska.

10. Graph showing composite of generalized lithologic description and geophysical logs for test hole 10-SP-11, Kimball County, Nebraska.

11. Graph showing composite of generalized lithologic description and geophysical logs for test hole 11-SP-11, Kimball County, Nebraska.

12. Graph showing composite of generalized lithologic description and geophysical logs for test hole 1-CC-11, Cheyenne County, Nebraska. 
13. Graph showing composite of generalized lithologic description and geophysical logs for test hole 2-CC-11, Cheyenne County, Nebraska.....

14. Graph showing composite of generalized lithologic description and geophysical logs for test hole 3-CC-11, Cheyenne County, Nebraska.

15. Graph showing composite of generalized lithologic description and geophysical logs for test hole 4-CC-11, Cheyenne County, Nebraska.

16. Graph showing composite of generalized lithologic description and geophysical logs for test hole 5-CC-11, Cheyenne County, Nebraska.

17. Graph showing composite of generalized lithologic description and geophysical logs for test hole 6-CC-11, Cheyenne County, Nebraska.

18. Graph showing composite of generalized lithologic description and geophysical logs for test hole 7-CC-11, Cheyenne County, Nebraska.

19. Graph showing composite of generalized lithologic description and geophysical logs for test hole 8-CC-11, Cheyenne County, Nebraska .

20. Graph showing composite of generalized lithologic description and geophysical logs for test hole 9-CC-11, Cheyenne County, Nebraska.

21. Graph showing composite of generalized lithologic description and geophysical logs for test hole 10-CC-11, Cheyenne County, Nebraska.

22. Graph showing composite of generalized lithologic description and geophysical logs for test hole 1-DC-12, Deuel County, Nebraska .

23. Graph showing composite of generalized lithologic description and geophysical logs for test hole 2-DC-12, Deuel County, Nebraska .

24. Graph showing composite of generalized lithologic description and geophysical logs for test hole 3-DC-12, Deuel County, Nebraska ..

25. Graph showing composite of generalized lithologic description and geophysical logs for test hole 4-DC-12, Deuel County, Nebraska ...

26. Graph showing composite of generalized lithologic description and geophysical logs for test hole 5-DC-12, Deuel County, Nebraska

27. Graph showing composite of generalized lithologic description and geophysical logs for test hole 6-DC-12, Deuel County, Nebraska ..

28. Graph showing composite of generalized lithologic description and geophysical logs for test hole 7-DC-12, Deuel County, Nebraska .

29. Graph showing composite of generalized lithologic description and geophysical logs for test hole 8-DC-12, Deuel County, Nebraska .

30. Graph showing composite of generalized lithologic description and geophysical logs for test hole 9-DC-12, Deuel County, Nebraska. The groundwater levels depicted were measured in the High Plains aquifer, Brule sand aquifer, and the Chadron aquifer .......45

\section{Tables}

1. Geology and hydrogeologic characteristics of the study area of western Nebraska......5

2. Site identifiers, geographic location, and selected drilling data for test holes, Kimball, Cheyenne, and Deuel Counties, Nebraska, 2011-12. 


\section{Acknowledgments}

The authors thank the South Platte Natural Resources District and the Nebraska Environmental Trust for their financial support. Acknowledgement is extended to Chris Kaiser of the South Platte Natural Resources District for securing access to all drilling locations and handling administrative duties associated with this project. The authors also thank the participating landowners for granting access to their properties for this study. 
Conversion Factors

\begin{tabular}{|c|c|c|}
\hline Multiply & By & To obtain \\
\hline \multicolumn{3}{|c|}{ Length } \\
\hline inch (in.) & 2.54 & centimeter $(\mathrm{cm})$ \\
\hline inch (in.) & 25.4 & millimeter (mm) \\
\hline foot (ft) & 0.3048 & meter $(\mathrm{m})$ \\
\hline mile (mi) & 1.609 & kilometer (km) \\
\hline \multicolumn{3}{|c|}{ Area } \\
\hline acre & 4,047 & square meter $\left(\mathrm{m}^{2}\right)$ \\
\hline acre & 0.4047 & hectare (ha) \\
\hline acre & 0.004047 & square kilometer $\left(\mathrm{km}^{2}\right)$ \\
\hline square foot $\left(\mathrm{ft}^{2}\right)$ & 0.09290 & square meter $\left(\mathrm{m}^{2}\right)$ \\
\hline square mile $\left(\mathrm{mi}^{2}\right)$ & 2.590 & square kilometer $\left(\mathrm{km}^{2}\right)$ \\
\hline \multicolumn{3}{|c|}{ Flow rate } \\
\hline gallon per minute (gal/min) & 0.06309 & liter per second $(\mathrm{L} / \mathrm{s})$ \\
\hline foot per day (ft/d) & 0.3048 & meter per day $(\mathrm{m} / \mathrm{d})$ \\
\hline inch per year (in/yr) & 25.4 & millimeter per year $(\mathrm{mm} / \mathrm{yr})$ \\
\hline \multicolumn{3}{|c|}{ Transmissivity* $^{*}$} \\
\hline foot squared per day $\left(\mathrm{ft}^{2} / \mathrm{d}\right)$ & 0.09290 & meter squared per day $\left(\mathrm{m}^{2} / \mathrm{d}\right)$ \\
\hline
\end{tabular}

Temperature in degrees Fahrenheit $\left({ }^{\circ} \mathrm{F}\right)$ may be converted to degrees Celsius $\left({ }^{\circ} \mathrm{C}\right)$ as follows: ${ }^{\circ} \mathrm{C}=\left({ }^{\circ} \mathrm{F}-32\right) / 1.8$.

Vertical coordinate information is referenced to the National Geodetic Vertical Datum of 1929 (NGVD 29).

Horizontal coordinate information is referenced to the North American Datum of 1983 (NAD 83).

*Transmissivity: The standard unit for transmissivity is cubic foot per day per square foot times foot of aquifer thickness [( $\left.\left.\mathrm{ft}^{3} / \mathrm{d}\right) / \mathrm{ft}^{2}\right] \mathrm{ft}$. In this report, the mathematically reduced form, foot squared per day $\left(\mathrm{ft}^{2} / \mathrm{d}\right)$, is used for convenience. 


\title{
Hydrostratigraphic Interpretation of Test-Hole and Borehole Geophysical Data, Kimball, Cheyenne, and Deuel Counties, Nebraska, 2011-12
}

\author{
By Christopher M. Hobza and Steven S. Sibray
}

\section{Abstract}

Recently (2004) adopted legislation in Nebraska requires a sustainable balance between long-term supplies and uses of surface-water and groundwater and requires Natural Resources Districts to understand the effect of groundwater use on surface-water systems when developing a groundwatermanagement plan. The South Platte Natural Resources District (SPNRD) is located in the southern Nebraska Panhandle and overlies the nationally important High Plains aquifer. Declines in water levels have been documented, and more stringent regulations have been enacted to ensure the supply of groundwater will be sufficient to meet the needs of future generations. Because an improved understanding of the hydrogeologic characteristics of this aquifer system is needed to ensure sustainability of groundwater withdrawals, the U.S. Geological Survey, in cooperation with the SPNRD, Conservation and Survey Division of the University of Nebraska-Lincoln, and the Nebraska Environmental Trust, began a hydrogeologic study of the SPNRD to describe the lithology and thickness of the High Plains aquifer. This report documents these characteristics at 29 new test holes, 28 of which were drilled to the base of the High Plains aquifer.

Herein the High Plains aquifer is considered to include all hydrologically connected units of Tertiary and Quaternary age. The depth to the base of aquifer was interpreted to range from 37 to 610 feet in 28 of the 29 test holes. At some locations, particularly northern Kimball County, the base-of-aquifer surface was difficult to interpret from drill cutting samples and borehole geophysical logs. The depth to the base of aquifer determined for test holes drilled for this report was compared with the base-of-aquifer surface interpreted by previous researchers. In general, there were greater differences between the base-of-aquifer elevation reported herein and those in previous studies for areas north of Lodgepole Creek compared to areas south of Lodgepole Creek. The largest difference was at test hole 5-SP-11, where an Ogallala-filled paleovalley previously had been interpreted based on relatively sparse test-hole data west of 5-SP-11. The base of aquifer near test hole 5-SP11 reported herein is approximately $230 \mathrm{ft}$ higher in elevation than previously interpreted. Among other test holes that are likely to have been drilled in Ogallala-filled paleovalleys, the greatest difference in the interpreted base of aquifer was for test hole 7-CC-11, northeast of Potter, Nebraska, where the base of aquifer is 180 feet deeper than previously interpreted.

Interpretation of test-hole and borehole geophysical data for 29 additional test holes will improve resource managers' understanding of the hydrogeologic characteristics, including aquifer thickness. Aquifer thickness, which is related to total water in storage, is not well quantified in the north and south tablelands. The additional hydrostratigraphic interpretations provided in this report will improve the hydrogeologic framework used in current (2014) and future groundwater models, which are the basis for many water-management decisions.

\section{Introduction}

Recently (2004) adopted legislation in Nebraska requires a sustainable balance between long-term water supplies and uses of surface- and groundwater (Ostdiek, 2009) and requires Natural Resources Districts (NRDs) to understand the effect of groundwater use on surface-water systems when developing a groundwater-management plan. The South Platte Natural Resources District (SPNRD) is located in the southern part of the Nebraska Panhandle and overlies the nationally important High Plains aquifer (fig. 1). Within its borders, the SPNRD manages groundwater use in three distinct but hydrologically connected geologic units within the High Plains aquifer. Declines in water levels have been documented (McGuire, 2013), and more stringent regulations have been enacted to ensure the supply of groundwater will be sufficient to meet the needs of future generations (South Platte Natural Resources District, 2009). An improved understanding of the hydrogeologic characteristics of these aquifers is needed to ensure that current management plans are adequate to sustain future groundwater withdrawals.

The U.S. Geological Survey (USGS), in cooperation with the SPNRD, Conservation and Survey Division of the University of Nebraska-Lincoln, and the Nebraska Environmental 


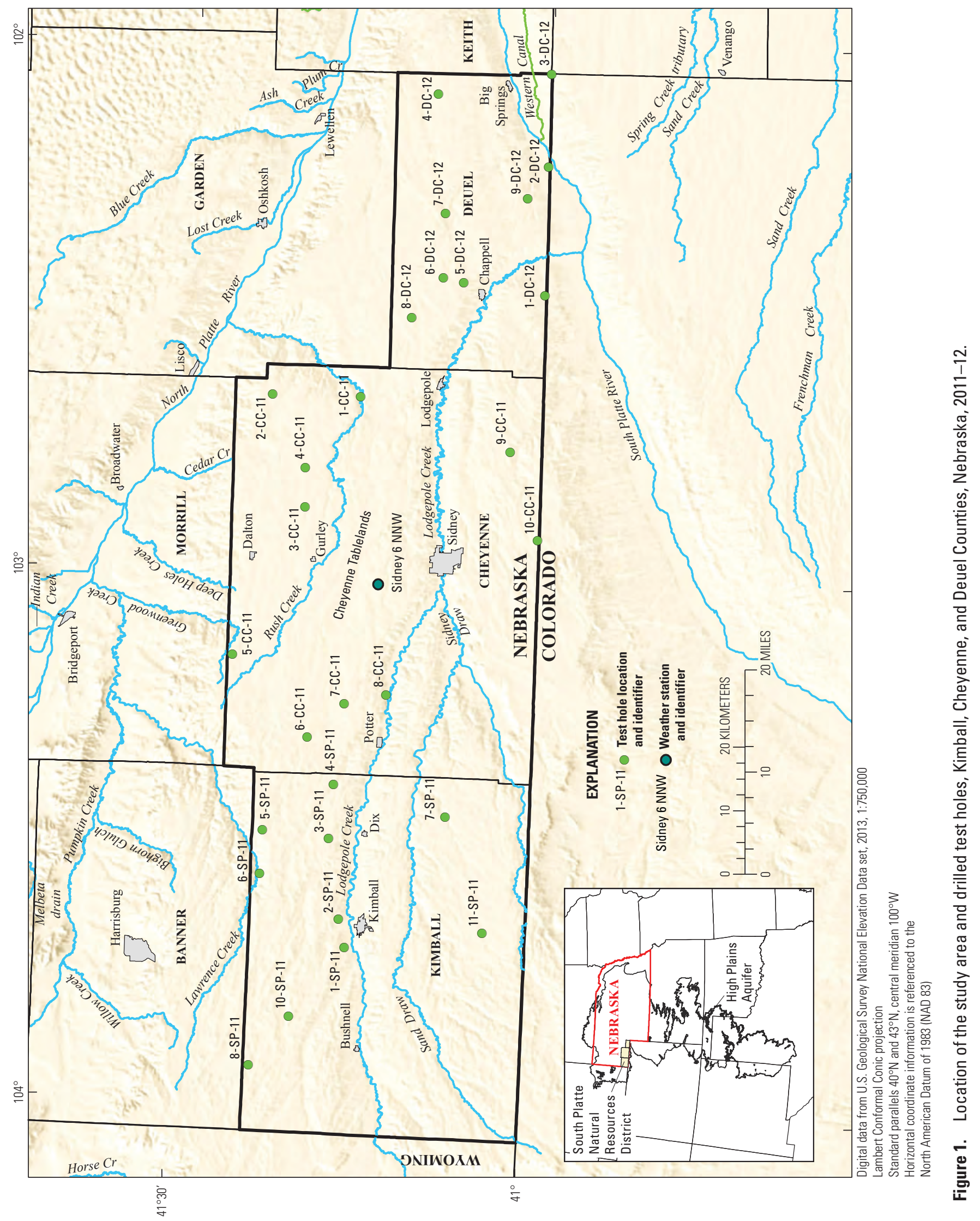


Trust, began in 2011 a hydrogeologic study of the SPNRD to describe the lithology and thickness of the High Plains aquifer underlying the SPNRD. This study included drilling 29 test holes, 28 of which were drilled to the base of the High Plains aquifer. The hydrostratigraphic interpretation of the additional test-hole information will improve the geologic framework used in current (2014) and future groundwater models, which are the basis for many water-management decisions.

\section{Purpose and Scope}

This report documents the methods of data collection and analysis, and presents test-hole and borehole geophysical logs and interpretations used to improve the knowledge of the hydrostratigraphy in the study area. The geologic and borehole geophysical data collected from the test holes are intended to refine interpretations in the base-of-aquifer elevation being used for groundwater models and to improve interpretations of geophysical data collected using airborne electromagnetic (AEM) surveys (Abraham and others, 2012; U.S. Geological Survey Crustal Geophysics and Geochemistry Science Center, 2014). The generalized lithologic logs and borehole-geophysical logs from 29 newly drilled test holes are included in this report.

\section{Previous Investigations}

Many geologic and groundwater investigations have included all or parts of the study area including Darton (1903 and 1905), Meinzer (1923), Bjorklund (1957), Lowry (1966), Barrash and Morin (1987), Diffendal (1990), Swinehart and Diffendal (1997), and Condon (2005). Bjorklund (1957) studied the groundwater and surface-water resources of the lower Lodgepole Creek valley and included water-level maps, geologic maps, and geologic cross-sections. Within the study area, Bjorklund (1957) also reported that a permeable zone underlies parts of Lodgepole Creek valley but pinches out near the valley walls. Lowry (1966) provided a map of these highly permeable zones in western Nebraska and eastern Wyoming. Barrash (1986) studied the hydraulic properties of the fractured part of the Brule Formation of the White River Group beneath Sidney Draw in Cheyenne County. Sibray and Zhang (1994) modeled the hydraulic behavior of a fracture zone in three dimensions. Steele and others (2007) completed a comprehensive investigation of groundwater movement, age, and quality near the city of Sidney, Nebraska. In this area, the three separate geologic units within the High Plains aquifer were determined to be hydrologically connected.

Groundwater models that encompass the entire study area have been used to address questions related to groundwater management and sustainability. As part of the Platte River Cooperative Hydrology Study (COHYST, http://cohyst. dnr.ne.gov/), the Western Model unit (Luckey and Cannia, 2006) was developed to support regulatory and management decisions for much of western Nebraska. Cannia and others (2006) developed a hydrostratigraphic framework and characterized underlying aquifers of the SPNRD and surrounding areas that was used in COHYST groundwater-flow models. To address concerns about future groundwater development, Luckey and others (1988) constructed a groundwater model that covered the entire High Plains aquifer. Work is ongoing (Qi and Christenson, 2010) to improve the earlier model (Luckey and others, 1988) and focuses on the entire High Plains aquifer using additional data and improved modeling techniques. As part of this recent modeling work, Stanton and others (2011) created a water budget for the High Plains aquifer and provided estimates of groundwater recharge and water use across the region, which includes the entire study area, and Houston and others (2013) released a compilation of geodatabases of hydrogeologic, remote-sensing, and waterbudget-component data.

\section{Study Area Description}

The study area is located in the southern part of the Nebraska Panhandle (fig. 1), includes all of Kimball, Cheyenne, and Deuel Counties, and covers approximately 2,600 square miles $\left(\mathrm{mi}^{2}\right)$. The study area is located within the High Plains section of the Great Plains physiographic province (Fenneman, 1946) and borders Wyoming to the west and Colorado to the south. Lodgepole Creek separates the north and south tablelands in the study area. The tablelands have nearly flat to gently rolling topography. The tablelands to the north, called the Cheyenne Tablelands, are more extensive, reaching the south edge of the Pumpkin Creek valley.

Land use in the study area is dominated by agriculture. Of the 1.66 million total acres of the study area, approximately 29 percent is rangeland and nonagricultural uses, 33 percent is nonirrigated (dry-land) crops, 8 percent is irrigated cropland, 21 percent is summer fallow or idle cropland, and 9 percent is enrolled in the Conservation Reserve Program and planted with native warm season grasses (South Platte Natural Resources District, 2009). In general, the amount of rangeland decreases and cropland increases from west to east (Center for Advance Land Management Information Technology, 2007). Irrigation demands are predominantly supplied with groundwater; however, some surface-water irrigation is present in southeastern Deuel County. The Western Irrigation District operates and maintains the Western Canal (fig. 1), which supplies approximately 23,900 acres, most of which are located outside the study area to the east (Luckey and Cannia, 2006). Historically, there have been surface-water diversions from Lodgepole Creek (Darton, 1903), though no diversion data were reported by Luckey and Cannia (2006).

The climate in the study area is characterized by cold winters and warm summers typical of continental mid-latitude locations (Luckey and Cannia, 2006). From 1908 to 2013 the mean monthly high temperatures ranged from 39.3 degrees Fahrenheit $\left({ }^{\circ} \mathrm{F}\right)$ to $88.9^{\circ} \mathrm{F}$, whereas mean monthly lows ranged 
from $12.0^{\circ} \mathrm{F}$ to $57.6^{\circ} \mathrm{F}$, for January and July, respectively (High Plains Regional Climate Center, 2013). During the same period, the mean annual precipitation was 16.8 inches (in.) at the Sidney 6 NNW weather station (fig. 1) (High Plains Regional Climate Center, 2013). Seasonality of precipitation is strong, with the greatest precipitation falling during the spring and summer months. Luckey and Cannia (2006) reported annual lake evaporation rates of about 47 in. that do not vary much throughout the study area.

Lodgepole Creek is the main watercourse that flows through the study area from west to east before emptying into the South Platte River in Colorado (fig. 1). Flow in Lodgepole Creek is typically ephemeral or intermittent (Bjorklund, 1957; Steele and others, 2007). Some reaches of Lodegpole Creek have sustained flow, especially during the nonirrigation season (October to April) (Steele and others, 2007). The tributaries of Lodgepole Creek, including Sidney Draw, are ephemeral streams and only provide flow after times of intense rainfall (Bjorklund, 1957). A major surface-water divide crosses the study area in Cheyenne and Kimball Counties, where the north half drains into Rush Creek and other tributaries that lead to the North Platte River (fig. 1).

Most groundwater recharge in the study area is focused along Lodgepole Creek and its tributaries and occurs after intense precipitation (Bjorklund, 1957); however, the author did not quantify amounts. Using the SWASP soil-water simulation program, Dugan and Zelt (2000) estimated the nonirrigated potential recharge at 0.5 to 1.0 inch per year (in/ yr). Using the Soil-Water-Balance model, Stanton and others (2011) estimated recharge to average 0.1 to $0.5 \mathrm{in} / \mathrm{yr}$ for 1940 to 1949 and 2000 to 2009 for all land uses.

\section{Geologic Setting and Hydrogeology}

The study area overlies the High Plains aquifer (fig. 1). For the purposes of this report, the High Plains aquifer is considered to include all hydrologically connected geologic units of Tertiary and Quaternary age (table 1). According to Gutentag and others (1984), within the study area, these rocks are the fractured parts of the upper units of the Oligocene-age Brule Formation of the White River Group, the Miocene- to Oligocene-age Arikaree Group, the Miocene-age Ogallala Formation, and Quaternary-age alluvial deposits. The fractured Oligocene-age Brule Formation of the White River Group underlies parts of Sidney Draw and Lodgepole Creek (Bjorklund, 1957; Lowry, 1966). Within the study area, either the unfractured Brule Formation of the White River Group or undifferentiated Cretaceous deposits form the base of the aquifer. Some of the nomenclature used in this report is commonly used by the Conservation and Survey Division of the University of Nebraska-Lincoln (Korus and Joeckel, 2011). Unless noted in table 1, all other names for geologic and hydrostratigraphic units are used by the USGS.

The oldest geologic units relevant to this report are Cretaceous in age. The Pierre Shale is a gray to black marine shale that serves as a regional confining unit within the study area. Overlying the Pierre Shale is the Fox Hills Formation, a Cretaceous-age fine to medium-grained sandstone and shale. The Fox Hills Formation forms an aquifer in extreme southwestern Kimball County that is typically only used for domestic or stock purposes (Korus and Joeckel, 2011) when no other sources of water are available (Cannia and others 2006).

The Eocene-age Chadron Formation of the White River Group (referred to herein as the Chadron) is the oldest Tertiary unit in the study area and represents the oldest deposition following the retreat of the Western Interior Seaway (Condon, 2005). The upper part of the Chadron is a claystone and mudstone that may contain bentonitic shales that serve as a confining unit to separate the unconfined zones of the High Plains aquifer from the underlying confined aquifers. This confining layer, which is typically 50 to 60 feet (ft) thick in the study area, overlies a basal sandstone that is typically 15 to $20 \mathrm{ft}$ thick (Abraham and others, 2012). The total thickness of the Chadron can be more than $300 \mathrm{ft}$ thick in some paleovalleys. Swinehart and others (1985) indicate that this basal sandstone occurs in the eastern half of the study area and is restricted to several Eocene paleovalleys in Kimball and western Cheyenne Counties. Other researchers have reclassified and renamed the basal sandstone as the Chamberlain Pass Formation (Evans and Terry, 1994; Terry and Evans, 1994). The basal sandstone is a water-bearing unit though rarely used in the study area because of its depth and poor water quality (Cannia and others, 2006).

The Brule Formation of the White River Group (referred to herein as the Brule) underlies the entire study area and in most locations forms the base of the principal aquifer. The Brule underlies Quaternary-age undifferentiated deposits of alluvial, colluvial, and eolian origin in modern valleys and the Ogallala Formation beneath the tablelands. The Brule is composed of a thick sequence of siltstone and mudstone that in places can exceed $600 \mathrm{ft}$ (Steele and others, 2007). Although rare, the Brule may contain fluvial sand and gravel deposits that may yield moderate amounts of water to wells (Cannia and others, 2006). Steele and others (2007) described and mapped one paleochannel deposit north of Sidney that was roughly 0.5 mile (mi) wide and traceable for approximately $6 \mathrm{mi}$.

In places, the upper Brule can be fractured and is capable of supplying large amounts of water to wells. Bjorklund (1957) reported the existence of a horizontal permeable zone, roughly 10 to $15 \mathrm{ft}$ thick, underlying parts of Lodgepole Creek valley that served as an important water source for large capacity wells. Sibray and Zhang (1994) reported that although the fracture zones can yield large amounts of water to wells, the storage coefficient is very low. Because of this, water levels can fluctuate substantially, which can often result in insufficient water yield to high-capacity wells during times of prolonged drought (Steele and others, 2007). Barrash and Ralston (1991) reported that the horizontal hydraulic conductivity of the fractured Brule west of Sidney ranged 


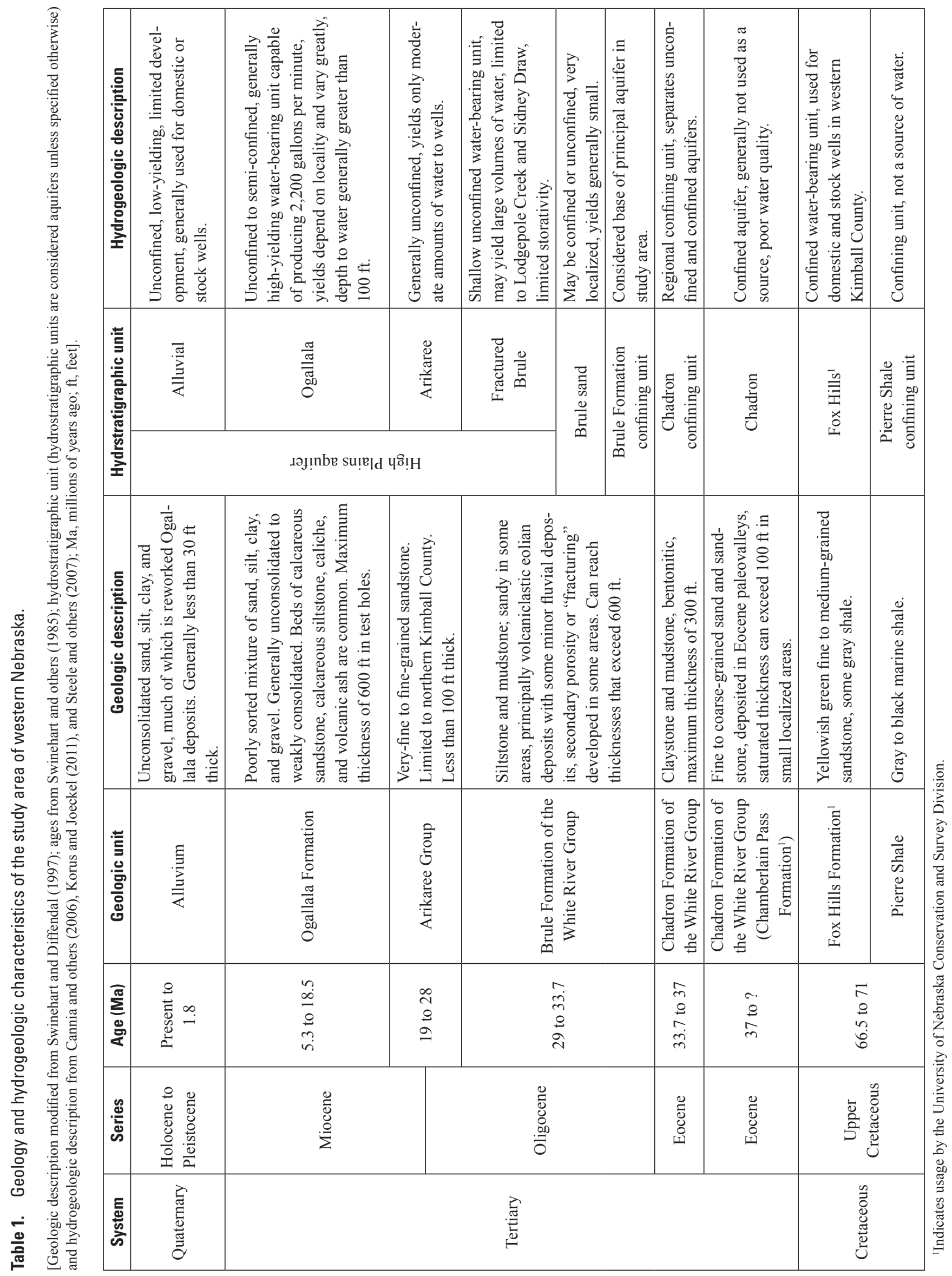


from 3,000 to 11,000 feet per day (ft/d), derived by analytical modeling of drawdown data. In a later aquifer test, Sibray and Zhang (1994) examined the same area and estimated a hydraulic conductivity value of $20,000 \mathrm{ft} / \mathrm{d}$ using a finite-difference three-dimensional numerical groundwater model (McDonald and Harbaugh, 1988). The aquifer test led by Sibray and Zhang (1994) also included additional wells completed above and below the fractured zone. The wells completed below the fracture zone indicated a slower response, indicating a lack of vertical fractures at depth.

The Arikaree Group (herein referred to as the Arikaree) is a very-fine to fine-grained sandstone. Deposition of this unit was fluvial and eolian. This unit typically has been eroded away within the study area but outcrops and subcrops have been noted in extreme northern Kimball County (Swinehart and others, 1985; Cannia and others, 2006). This unit, a subunit of the High Plains aquifer, is considered an unconfined, water-bearing unit capable of yielding moderate amounts of water to wells and is typically not a suitable supply for highcapacity wells (Cannia and others, 2006).

The Ogallala Formation (referred to herein as the Ogallala) underlies the entire study area with the exception of the lower Lodgepole Creek valley and Sidney Draw, where the unit has been eroded away (Bjorklund, 1957). The Ogallala is the principal geologic unit in the High Plains aquifer and can reach a thickness of nearly $600 \mathrm{ft}$ beneath the study area (University of Nebraska-Lincoln, Conservation and Survey Division, 2013). The Ogallala is composed of a poorly sorted mixture of sand, silt, clay, and gravel (Condra and Reed, 1943). The Ogallala is largely the result of fluvial deposition, but other depositional environments including eolian and lacustrine have been discussed by other researchers (Diffendal, 1982; Helland and Diffendal 1993; Swinehart and Diffendal, 1989). The Ogallala generally is unconsolidated or weakly consolidated but contains layers of sandstone cemented by calcium carbonate. Previous researchers have proposed subdivisions of this unit within the study area, but those have since been abandoned because of the difficulty correlating lithologic units (Diffendal, 1990). Much of the Ogallala was deposited by aggrading streams that filled paleovalleys eroded into older rocks (Swinehart and others, 1985). The location of Ogallalafilled paleovalleys has been proposed by previous researchers (Swinehart and others, 1985), but may represent only a fraction of the drainage systems that existed during Miocene time. Much of the deposition was restricted to valleys along drainage systems originating from mountains in Wyoming and Colorado (Swinehart and others, 1985). Borchert (1976) documented the presence of several Ogallala paleovalleys immediately west of Kimball County. These paleovalleys trended to the east and most likely cut across the northern part of Kimball County.

The Ogallala part of the High Plains aquifer supplies all wells in the Cheyenne Tablelands and south tablelands within the study area. Wells completed in the Ogallala can yield up to 2,200 gallons per minute (gpm) (Steele and others, 2007) and average $860 \mathrm{gpm}$ (Bjorklund, 1957). Yields to wells are highly variable depending on the local geology. Water levels in the Ogallala range from near land surface within the upper Lodgepole Creek valley to greater than $250 \mathrm{ft}$ in the Cheyenne Tablelands. To the south of Lodgepole Creek, the base of the Ogallala is higher in elevation and supports far fewer high-capacity wells because of insufficient saturated thickness (Steele and others, 2007).

Within the Ogallala aquifer, properties such as hydraulic conductivity and specific yield can vary greatly. Steele and others (2007) cited a report completed by Bishop-Brogden and Associates, Inc., that estimated the aquifer properties of an unconsolidated channel sand north of Sidney, where the transmissivity was estimated as 27,000 square feet per day $\left(\mathrm{ft}^{2} / \mathrm{d}\right)$ and hydraulic conductivity was $600 \mathrm{ft} / \mathrm{d}$. The specific yield was estimated between 0.20 and 0.25 . Within the study area, the Ogallala can contain unconsolidated sand, but is generally a mix of unconsolidated and consolidated deposits of very fine-grained sand, silt, and clay (Steele and others, 2007). Typical values for hydraulic conductivity and specific yield are likely to be closer to those reported by Irons and others (2012) for the Ogallala in central Nebraska. Based on aquifer tests completed approximately 170 miles east of Sidney, Nebr., Irons and others (2012) reported a range in hydraulic conductivity from 4.8 to $18 \mathrm{ft} / \mathrm{d}$ for individual wells. Houston and others (2013) reported estimates of aquifer properties for the entire High Plains aquifer using an approach similar to Gutentag and others (1984) by estimating aquifer properties based on lithologic descriptions of test holes. The more recent study (Houston and others, 2013) included test holes drilled in Kimball County, which are presented in this report. Excluding the test holes where the Ogallala was absent, the median hydraulic conductivity was estimated as $49 \mathrm{ft} / \mathrm{d}$, and the specific yield was 0.17 for all test holes in the study area.

The youngest aquifer within the study area is the Lodgepole Creek alluvium, which is also a subunit of the High Plains aquifer. The alluvial deposits consist of a heterogeneous mixture of sand, silt, clay, and gravel. This aquifer is generally thin throughout much of the study area and is not considered a major water source for high-capacity wells (Steele and others, 2007). This aquifer serves an important function by capturing overland runoff and facilitating recharge to high-capacity wells completed in the underlying Brule. The alluvium can become dry during the irrigation season (May to September) when high-capacity irrigation wells are pumped from the underlying Brule (Steele and others, 2007).

Groundwater flow is generally to the east and toward Lodgepole Creek or the South Platte River and its tributaries. A groundwater divide in the Cheyenne Tablelands, south of Rush Creek, separates flow to Lodgepole Creek from flow to the North Platte River (Steele and others, 2007) (fig. 1). The depth to groundwater ranges from near land surface in the Lodgepole Creek and South Platte River valleys to greater than $250 \mathrm{ft}$ in the Cheyenne Tablelands (Abraham and others, 2012). 


\section{Methods}

\section{Test-Hole Drilling and Borehole Geophysics}

The generalized lithologic descriptions and borehole geophysical logs for 29 test holes drilled in the study area are presented in the "Hydrostratigraphic Interpretation of TestHole and Borehole Geophysical Data" section and at the back of the report. Original copies of the lithologic logs of each test hole are filed at the USGS, Lincoln, Nebr. All borehole geophysical logs are archived in accordance with USGS protocol (U.S. Geological Survey, written commun., 2009). At the present time (2014), complete stratigraphic interpretations have not been assigned. Consequently, the stratigraphic units comprising the High Plains aquifer are undifferentiated, and generally only the base of the High Plains aquifer at each test hole has been reported.

\section{Test-Hole Drilling Method and Procedure}

Test-hole drilling with mud-rotary drilling equipment has been an integral part of groundwater and geologic studies in Nebraska for many years (Diffendal, 2000). Mud-rotary test-hole drilling and sampling required the use of drilling fluid suitable for the geologic conditions. As the drill stem was advanced, typically in 5-ft increments, the time required to advance each increment was recorded along with the drilling action. Drill cuttings were circulated to the surface, collected, examined immediately, and lithologically described. Described samples were bagged, labeled, and provided to the Conservation and Survey Division of the University of Nebraska-Lincoln (CSD) for further examination under a petrographic microscope before the final assignment of stratigraphic intervals and their inclusion in the state test-hole database (University of Nebraska-Lincoln, Conservation and Survey Division, 2013). Although the precise contacts of certain hydrostratigraphic units have not been determined, logged lithologic characteristics can provide information on the hydrostratigraphic units sampled. For example, in many test-hole logs published by CSD (Diffendal, 1999, 2000; Smith, 2000a, 2000b; University of Nebraska-Lincoln, Conservation and Survey Division, 2013), the Ogallala is indicated by presence of siliceous plant roots (rootlets). Other lithologic characteristics are summarized in table 1 . The location of each test hole is shown in figure 1, and test-hole locations and dates drilled are listed in table 2.

\section{Borehole Geophysical Data Collection}

Borehole geophysical data were collected within the mud- or drilling-fluid-filled hole. A suite of borehole logs were collected on a single run with a multiparameter, galvanic resistivity logging tool. Borehole logs were collected using either the Century 8144 Multi-Parameter electrical-log tool (Century Geophysical Corp., 2011) or the Mount Sopris 2PEA-250 tool (Mount Sopris Instruments, 2011). The Century 8144 tool measured long-normal (64 in.) and short-normal (16 in.) electrical resistivity, natural gamma radiation, spontaneous potential, and fluid resistivity. The Mount Sopris 2PEA-250 resistivity tool was threaded onto the 2PGA-250 tool (Mount Sopris Instruments, 2011) to create a multiparameter logger comparable to the Century 8144 electric-log tool. The Mount Sopris tool measured resistivity using an 8-, 16-, 32-, and 64-in. electrode spacing as well as natural gamma and spontaneous potential (Mount Sopris Instruments, 2011). The types of geophysical logs collected are briefly described in the following paragraphs. Further information regarding borehole geophysics can be found in reports such as Keys (1990).

Normal-resistivity logs measure the electrical resistivity of sediment, rocks, and water surrounding the borehole. Depending on the logging system used, the electrode spacing ranged from 8 in. to $64 \mathrm{in}$., each with a different volume of investigation. Short-normal logs have a smaller volume of investigation and, therefore, are affected more by the resistivity of the drilling fluid and the invaded zone that develops on the borehole wall. Correspondingly, long-normal logs have a larger volume of investigation and are less affected by drilling fluid. Intervals where these two logs diverge indicate areas of high permeability where drilling fluid has invaded the formation (Anderson and others, 2009).

Natural gamma logs measure natural gamma radiation being emitted by the formation surrounding the borehole (Keys, 1990). Clay tends to accumulate radioisotopes through adsorption and ion-exchange processes. Most clays, particularly illites, have high gamma activity because of the presence of potassium in their crystal structure. Therefore, zones of high gamma activity typically are interpreted as being clayrich. Volcanic ash, organic shale, and feldspathic or arkosic sandstones also can produce higher gamma responses (Anderson and others, 2009).

Spontaneous-potential logs (often referred to as selfpotential or SP) measure differences in the electrical potentials that develop in a borehole at lithologic or water-quality interfaces (Anderson, 2009). Differences in electrical potential often are caused by differences between the salinity of the borehole fluid and that of the formation fluid (Keys, 1990). When the borehole fluid is fresher than the formation fluid, electric current flow is such that SP will deflect in a negative direction; conversely, when the formation fluid is fresher than the borehole fluid, electric current flow is such that SP will deflect in a positive direction (Stanton and others, 2007).

Caliper logs were collected in 2012 for all test holes in Deuel County. The caliper log measures the borehole diameter with a spring loaded, three-arm probe. Changes in borehole diameter are affected by drilling procedure, the competency of the geologic units, and the presence of fractures (Keys, 1990). 


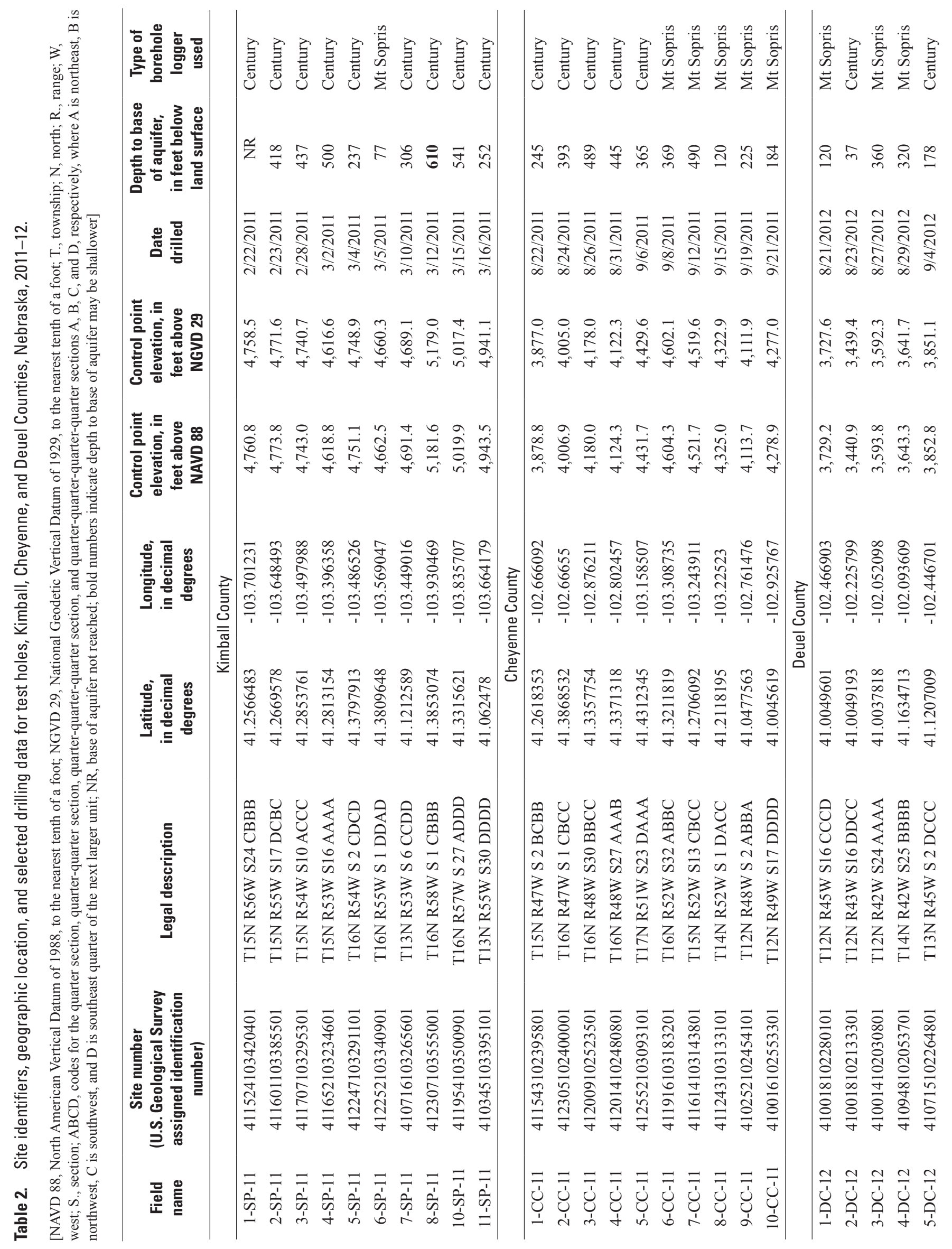




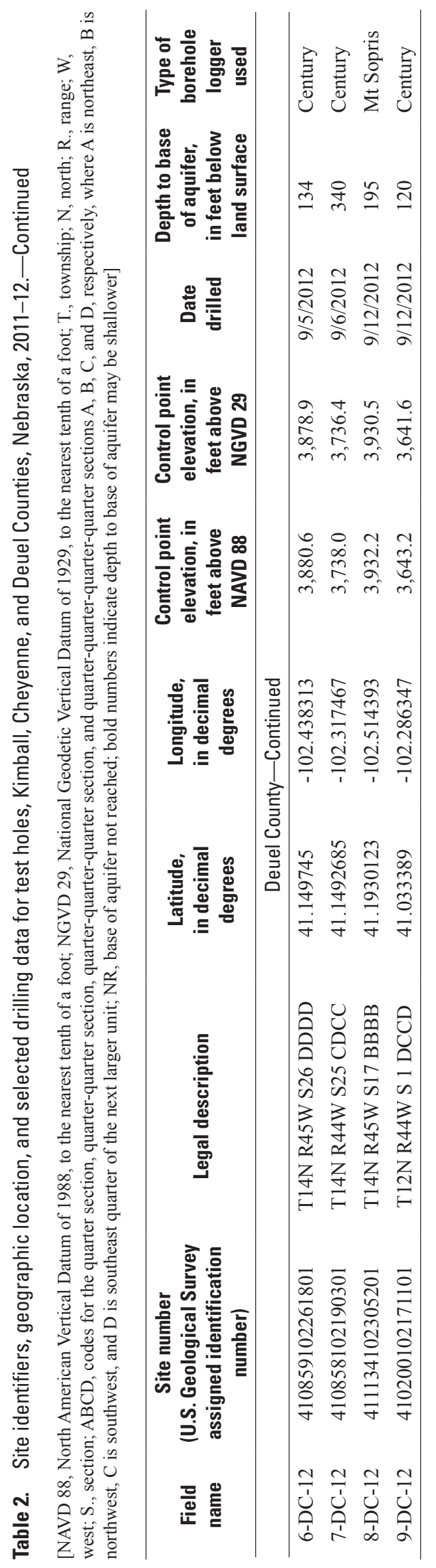




\section{Global Positioning System Survey}

After all test holes were completed, locations were surveyed with a survey-grade global positioning system (GPS). Horizontal and vertical coordinates were established through the use of the Global Navigation Satellite Systems (GNSS). Static GNSS surveying refers to collecting positioning data by setting up a GNSS receiver antenna over a single point, and allowing measurements to be collected from positioning satellites for an extended period of time (Rydlund and Densmore, 2012). The GNSS data collected during static surveys were later post-processed with data collected from nearby control stations to correct atmospheric interference errors and to produce survey-grade solutions.

Trimble R8 GNSS receivers (Trimble Navigation Limited, 2009) were used to collect static positioning data at each test-hole location. Since each test hole was completed as a monitoring well, a GNSS receiver was set up directly above a survey control point at each monitoring well. The survey control point was established in each concrete well pad by drilling a small hole with a masonry bit and gluing a nail in place. A 6.6-ft fixed-height tripod was centered atop the nail set in the well pad. Each receiver was configured to record positioning data every 15 seconds for at least 4 hours, after which the logged data were downloaded and the receiver moved to another test-hole location.

After each static-survey session, the logged data file was sent to the Online Positioning User Service (OPUS; $w w w$. ngs.noaa.gov/OPUS/) to determine the exact position of the surveyed test hole. OPUS is a quality-assured service provided by the National Geodetic Survey (NGS), where users can process single-base GNSS data through an online-user interface. OPUS processes logged data using continuously operating reference stations (CORS). For more information on static GNSS surveying, the reader is referred to Rydlund and Densmore (2012).

The geographic coordinates, control-point elevations, and other test-hole information are presented in table 2. Elevations received from OPUS are referenced to the North American Vertical Datum of 1988 (NAVD 88). The elevations were converted using the program CORPSCON, version 6.0 (http:// www.agc.army.mil/Missions/Corpscon.aspx), to the National Geodetic Vertical Datum of 1929 (NGVD 29) to match the vertical datum used in previous reports, such as Abraham and others (2012).

The accuracy of the solutions was reported as peak-topeak errors, which represent the difference between maximum and minimum value of the coordinates obtained from the three baseline solutions (Rydlund and Densmore, 2012). For all position solutions received from OPUS, greater than 80 percent of the logged observations were used, greater than 80 percent of ambiguities were fixed, and the vertical peak-topeak errors were less than $1 \mathrm{in}$., indicating that coordinates for all surveyed points met the criteria for USGS Level II singlebase Online Positioning User Service-Static (OPUS-S) survey accuracy (Rydlund and Densmore, 2012).

\section{Hydrostratigraphic Interpretation of Test-Hole and Borehole Geophysical Data}

Generalized lithologic descriptions and selected borehole geophysical logs for all test holes are presented in figures 2-30. An example test-hole with generalized lithologic description and borehole geophysical logs is shown in figure 2 . Logs from all other test holes can be found at the back of the report. Borehole geophysical logs include data for short- and long-normal resistivity (16 and 64 in. collected for Century and Mount Sopris tools; 8 and 32 in. normal for logs collected additionally with Mount Sopris tool), natural gamma activity, and spontaneous potential.

Shortly after each test hole was drilled, a monitoring well was installed within the existing borehole. The well was constructed to have the screened interval typically in the most productive zone of the aquifer. Water levels, measured by SPNRD staff shortly after well installation, are depicted on figures 2-30 to aid in the interpretation of the resistivity logs. In the case of test hole 9-DC-12, water levels from wells completed in Brule sand and the Chadron aquifer are also depicted (fig. 30).

The depth to the interpreted base of aquifer is given in table 2. Within the study area, the base of the High Plains aquifer typically coincides with the base of the Ogallala, which unconformably overlies the Brule Formation. In some areas, the Brule can contain minor amounts of fine sand or the overlying Ogallala may contain silt, making interpretations of the base-of-aquifer surface difficult. The Arikaree, although rare within the study area, is included in the High Plains aquifer (Gutentag and others, 1984; Korus and Joeckel, 2011) and has similar lithologic characteristics to lower parts of the Ogallala and upper parts of the Brule, which in some cases can further complicate interpretations.

In most cases, resistivity logs were used to interpret the base of the High Plains aquifer. The long- and short-normal resistivity logs can indicate the base of the principal aquifer by sharp contrasts in resistivity between the Brule Formation and the overlying units. Examining the long- and short-normal resistivity, the sediments overlying the Brule Formation have resistivities that range from less than 50 to greater than $250 \mathrm{ohm}$-meters (ohm-m). Resistivity for the Ogallala (units containing rootlets) typically ranged between 75 to $150 \mathrm{ohm}$ $\mathrm{m}$, but can extend from 50 to $200 \mathrm{ohm}-\mathrm{m}$, with higher resistivity values indicating the presence of coarser deposits or a greater degree of cementation of the sandstone units. Coarse sand and gravel deposits typically had resistivity ranges of $150 \mathrm{ohm}-\mathrm{m}$ to $250 \mathrm{ohm}-\mathrm{m}$ or greater. In contrast, the resistivity of the Brule Formation typically was less than $25 \mathrm{ohm}-\mathrm{m}$ and, in many cases, was less than $15 \mathrm{ohm}-\mathrm{m}$.

With the exception of 1-SP-11 (fig. 2), every test hole reached the base of the primary aquifer. The base of the aquifer was not reached in test hole 1-SP-11 because of a very 


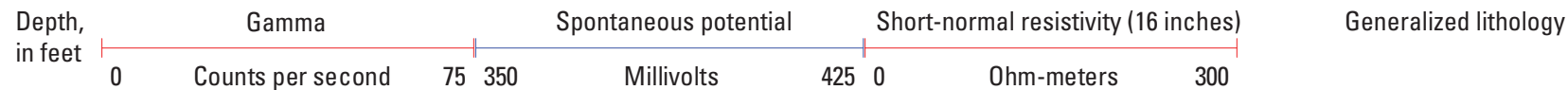

0

50

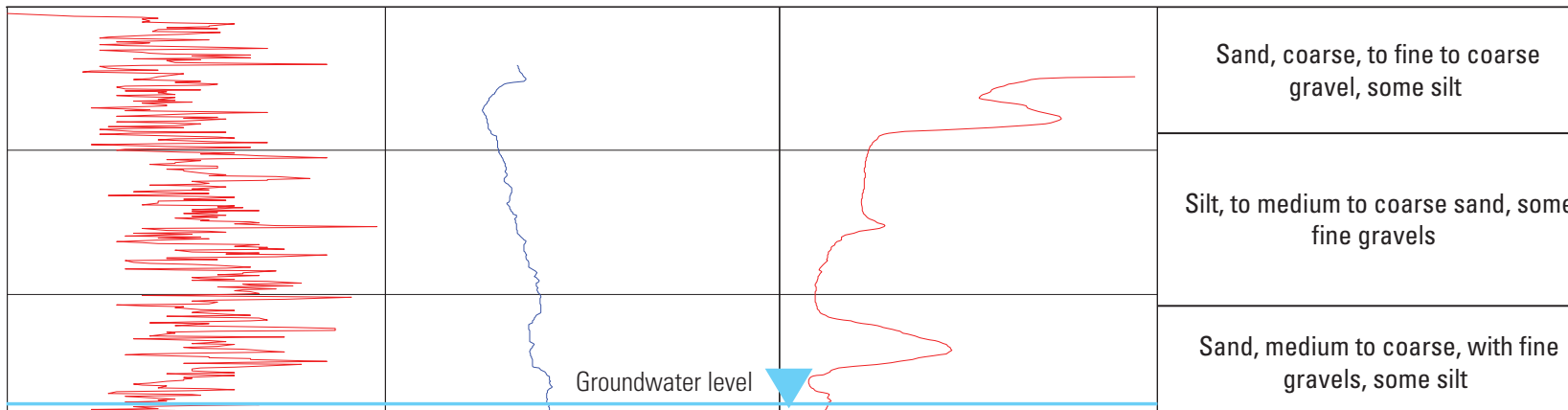

100

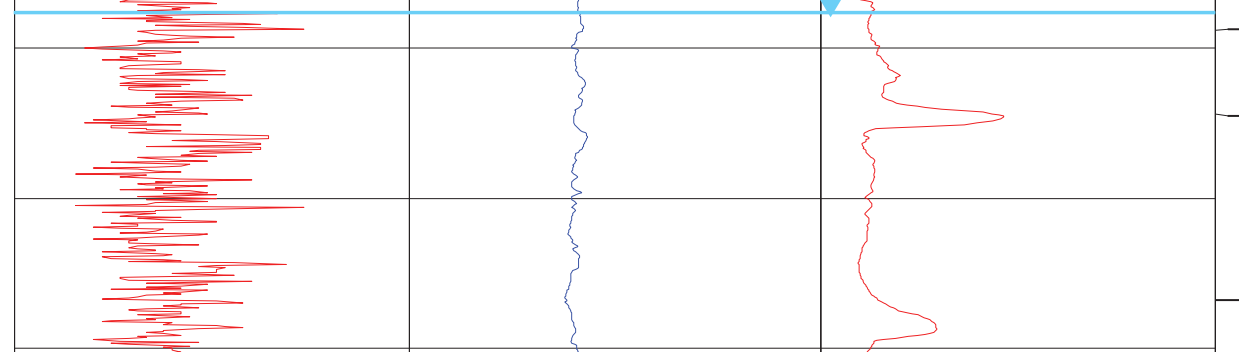

Sand to sandstone, very fine to coarse, some silt

Silt, sandy to clayey, some siltstone

150

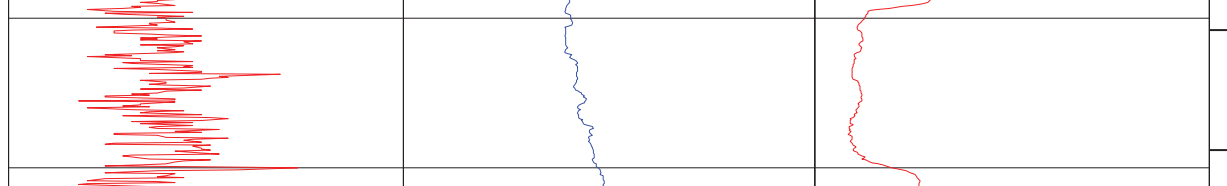

Silt, sandy to clayey, some siltstone

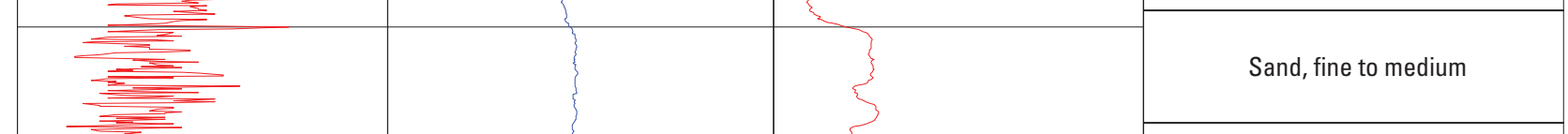

200
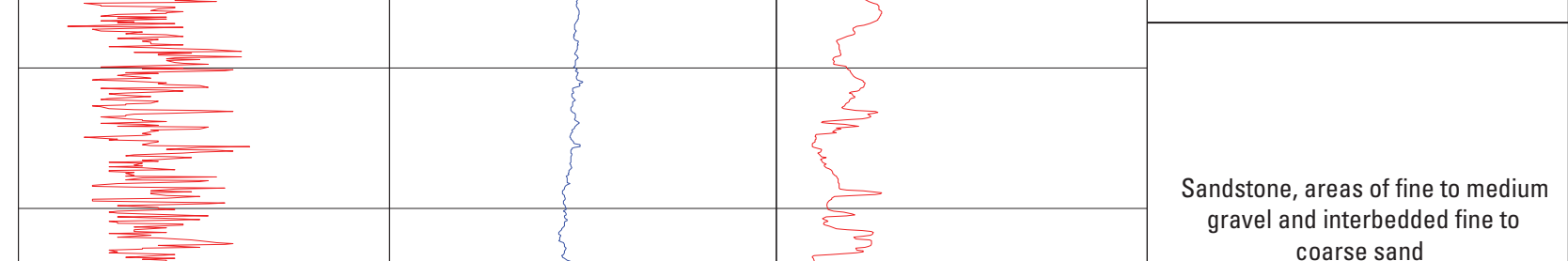

Sandstone, areas of fine to medium gravel and interbedded fine to coarse sand

250

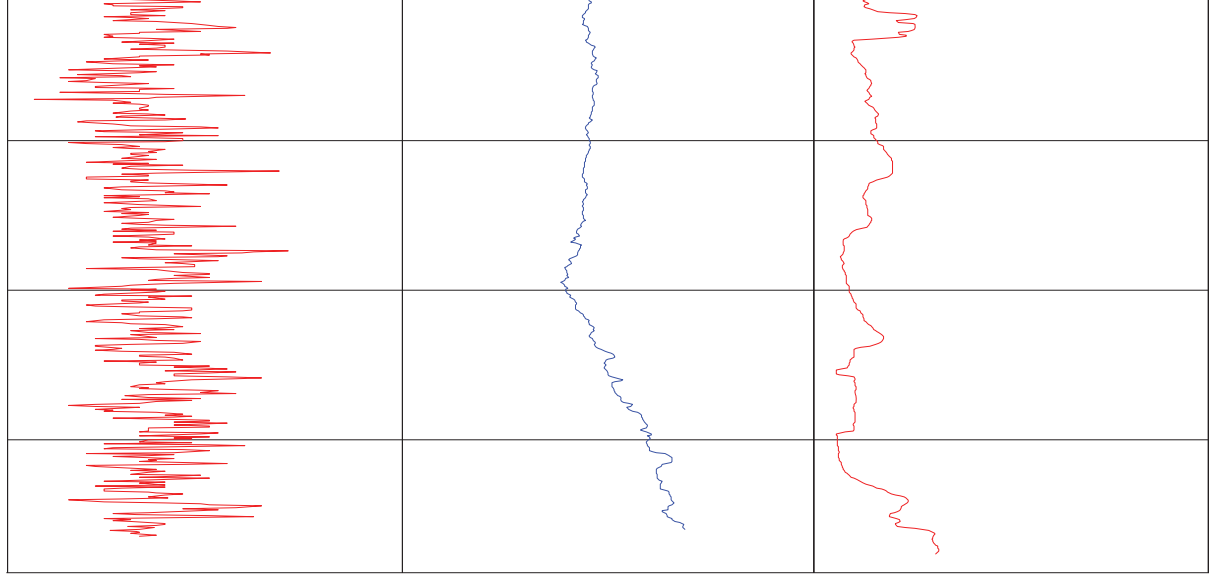

Silt-siltstone, some sandstone

Sandstone-siltstone

Figure 2. Composite of generalized lithologic description and geophysical logs for test hole 1-SP-11, Kimball County, Nebraska.

hard sandstone that could not be drilled through and refusal was declared. Test hole 9-DC-12 (fig. 30) was drilled through the basal sand and sandstone of the Chadron to the top of the Cretaceous-age Pierre Shale.
At times, there were problems while collecting borehole geophysical logs. Communication problems between the laptop computer and the borehole logging system prevented the collection of an entire $\log$ from the base of aquifer to land surface for test holes 3-CC-11 (fig. 14) and 4-DC-12 
(fig. 25). At times, the Century logging system produced erratic long-normal resistivity data with respect to what was recorded with the short-normal resistivity and known geology. For these cases, the long-normal resistivity was omitted from the composite geophysical logs.

With the exception of test hole 1-SP-11 (fig. 2), the base of aquifer has been interpreted for all test holes (figs. 3-30; table 2). At some locations, particularly northern Kimball County, the base-of-aquifer surface was difficult to interpret based on drill cutting samples and borehole geophysical logs. Here, the overlying Ogallala has been described to be similar in character to the upper part of the Brule Formation or possibly an outlier of the Arikaree. Another possible interpretation is that as streams flowed eastward, pieces of the Brule were eroded, transported, and deposited at the same time the Ogallala was deposited. A more likely interpretation is that similarities in the lithologic character between the Ogallala and the underlying Brule are due to similarities in the depositional environments. To ensure that the top of the Brule was reached, special attention was paid to the drilling action recorded at each 5-ft interval. Firm, competent Brule typically drills quietly and smoothly with an even rate of penetration. Communication between the on-site geologist and the driller was critical in making this determination. Test holes where the base of aquifer was interpreted within a gradational boundary include 5-SP-11, 1-CC-11, 2-CC-11, 8-CC-11, 9-CC-11, 1-DC-12, and 2-DC-12 (figs. 6, 12, 13, 19, 20, 22, and 23, respectively). In the cases of test holes 1-CC-11 and 2-CC-11 (figs. 12 and 13), the borehole geophysical logging system produced some erratic values on the long- and short-normal resistivity curves, making interpretation difficult.

In some instances, test holes from previous studies were used to aid in hydrostratigraphic interpretations. Test hole 8-SP-11 was drilled in northwest Kimball County (figs. 1 and 9). Lithologic descriptions of test hole 7-B-69 (Smith, 2000a; approximately 1.4 miles to the northwest; not shown on map) indicated that $461 \mathrm{ft}$ of Ogallala sediments overlie the top of the White River Group. Smith (2000a) was unsure if the overlying White River Group sediments were the "Brown Siltstone Beds" (Swinehart and others, 1985) of the White River Group. The lithologic descriptions and the resistivity curve on the borehole geophysical log for test hole 7-B-69 indicate no clear distinction between the overlying Ogallala and the White River Group sediments; however, there is a deflection to the left on the spontaneous-potential log (University of NebraskaLincoln, Conservation and Survey Division, 2013). Smith (2000a) indicates that silt and siltstone were reached at a depth of $630 \mathrm{ft}$ (4,513 ft above NGVD 29). The lithologic description of test hole 8-SP-11 indicates that firm, competent Brule Formation was drilled at a depth of $610 \mathrm{ft}(4,569 \mathrm{ft}$ above NGVD 29) (fig. 9). Above this interface, the normal resistivity $\log$ (fig. 9) displayed a similar character to the normal resistivity of test hole 7-B-69 because there is no obvious indication of the interface between the base of the Ogallala and the top of the Brule. The generalized lithologic log of test hole 8-SP-11 indicates the presence of siltstone mixed in with very fine to fine sand and sandstone. The base-of-aquifer surface in this case is interpreted to be at the top of the lower interval of firm siltstone at $610 \mathrm{ft}$ (4,569 ft above NGVD 29), although it is possible the Brule was reached at a shallower depth.

Test hole 10-SP-11 was drilled in northern Kimball County approximately $6 \mathrm{mi}$ southeast of test hole 8-SP-11 (fig. 1). At test hole 10-SP-11, the base of aquifer is interpreted at $541 \mathrm{ft}$ below land surface at the top of a 59-ft interval of greenish-gray, well-cemented very fine grained sandstone (fig. 10) that is interpreted to be the Fox Hills Formation. The resistivity of this unit was about $25 \mathrm{ohm}-\mathrm{m}$, and the recorded rate of penetration was slow, which is characteristic of this geologic unit. At this location, it seems that the Brule has been completely eroded away. Approximately $1.6 \mathrm{mi}$ to the northwest of test hole 10-SP-11 is test hole 10-ANB-70 (not shown on map). Smith (2000b) did not provide an interpretation for the bottom of the Ogallala at this location; however, it was noted that beds below $545 \mathrm{ft}$ (4,545 ft above NGVD 29) may be older than the Ogallala. Below $545 \mathrm{ft}$ the lithology was described as sandstone, siltstone, and clay before a chert was reached at $614 \mathrm{ft}(4,476 \mathrm{ft}$ above NGVD 29). No geophysical logs were collected for test hole 10-ANB-70. In places where the Brule has been eroded away, Cannia and others (2006) interpreted the base of aquifer at the top of the Cretaceous units. The base of aquifer for test hole 10-SP-11 is interpreted at $541 \mathrm{ft}$ below land surface (4,476 ft above NGVD 29).

The depth to the base of aquifer determined for test holes drilled for this report were compared with the base-of-aquifer surface interpreted by Abraham and others (2012). In general, there were greater differences in the reported base-of-aquifer elevation north of Lodgepole Creek compared to areas south of Lodgepole Creek. The largest difference was noted at test hole 5-SP-11 where an Ogallala-filled paleovalley previously had been interpreted based on relatively sparse test-hole data west of 5-SP-11. The base of aquifer near test hole 5-SP-11 reported herein is approximately $230 \mathrm{ft}$ higher in elevation than that interpreted by Abraham and others (2012). Other test holes are likely to have been drilled in Ogallala-filled paleovalleys, including test holes 3-SP-11, 4-SP-11, 8-SP-11, 10-SP-11, 1-CC-11, and 7-CC-11. The greatest difference in base-of-aquifer elevation was noted for test hole 7-CC-11, which was drilled in a buried paleovalley northeast of Potter, Nebr. (fig. 1). Here the base of aquifer (top of Brule; fig. 18) was drilled $180 \mathrm{ft}$ deeper than previously interpreted by Abraham and others (2012).

\section{Summary}

Recently (2004) adopted legislation in Nebraska requires a sustainable balance between long-term water supplies and uses of surface-water and groundwater and requires Natural Resources Districts (NRDs) to understand the effect of groundwater use on surface-water systems when developing a groundwater-management plan. The South Platte Natural 
Resources District (SPNRD) is located in the southern part of the Nebraska Panhandle and overlies the nationally important High Plains aquifer. Declines in water levels have been documented, and more stringent regulations have been enacted to ensure the supply of groundwater will be sufficient to meet the needs of future generations. The U.S. Geological Survey (USGS), in cooperation with the SPNRD, Conservation and Survey Division of the University of Nebraska-Lincoln, and the Nebraska Environmental Trust, began a hydrogeologic study of the SPNRD to describe the lithology and thickness of the High Plains aquifer underlying the SPNRD. This study included drilling 29 test holes, 28 of which were drilled to the base of the High Plains aquifer. The additional hydrostratigraphic interpretations provided in this report will improve the hydrogeologic framework used in current (2014) and future groundwater models, which are the basis for many watermanagement decisions.

The study area is located in the southern part of the Nebraska Panhandle and includes all of Kimball, Cheyenne, and Deuel Counties. The study area is located within the High Plains section of the Great Plains physiographic province and borders Wyoming to the west and Colorado to the south. Lodgepole Creek separates the north and south tablelands in the study area. Land use in the study area is dominated by agriculture. In general, the amount of rangeland decreases and cropland increases from west to east. Irrigation demands are predominantly supplied with groundwater; however, some surface-water irrigation is present in southeastern Deuel County. Lodgepole Creek is the main watercourse that flows through the study area from west to the east before emptying into the South Platte River in Colorado. Flow in Lodgepole Creek is typically ephemeral or intermittent. Some reaches of Lodegpole Creek have sustained flow, especially during certain times of the nonirrigation season (October to April). The tributaries of Lodgepole Creek, including Sidney Draw, are ephemeral streams and only provide flow after times of intense rainfall.

The study area overlies the High Plains aquifer. For the purposes of this report, the High Plains aquifer is considered to include all hydrologically connected geologic units of Tertiary and Quaternary age. Within the study area, these rocks are the fractured upper parts of the Oligocene-age Brule Formation of the White River Group, the Miocene- to Oligoceneage Arikaree Group, the Miocene-age Ogallala Formation, and Quaternary-age alluvial deposits.

The Ogallala Formation (referred to herein as the Ogallala) underlies the entire study area with the exception of the lower Lodgepole Creek valley and Sidney Draw, where the unit has been eroded away. The Ogallala is the principal geologic unit in the High Plains aquifer and can reach a thickness of nearly 600 feet (ft) beneath the study area. The Ogallala is composed of a poorly sorted mixture of sand, silt, clay, and gravel. The Ogallala is largely the result of fluvial deposition, but other depositional environments including eolian and lacustrine have been discussed by other researchers. The Ogallala generally is unconsolidated or weakly consolidated but contains layers of sandstone cemented by calcium carbonate.
The Ogallala part of the High Plains aquifer supplies all wells in the north and south tablelands within the study area. Wells completed in the Ogallala can yield up to 2,200 gallons per minute (gpm) and average $860 \mathrm{gpm}$. Yields to wells are highly variable depending on the local geology. Water levels in the Ogallala range from near land surface within the upper Lodgepole Creek valley to greater than $250 \mathrm{ft}$ in the Cheyenne Tablelands.

The depth to the base of aquifer was interpreted to range from 37 to $610 \mathrm{ft}$ in 28 of the 29 test holes. At some locations, particularly northern Kimball County, the base-of-aquifer surface was difficult to interpret based on drill cutting samples and borehole geophysical logs. In those areas, the overlying Ogallala has been described to be similar in character to the upper part of the Brule Formation or possibly an outlier of the Arikaree Group. A likely interpretation is that similarities in the lithologic character between the Ogallala and the underlying Brule are due to similarities in the depositional environments.

In some instances, test holes from previous studies were used to aid in hydrostratigraphic interpretations. Lithologic descriptions of test hole 7-B-69 (approximately 1.4 miles northwest from test hole 8-SP-11) indicated that at least $461 \mathrm{ft}$ of Ogallala sediments overlie the top of the White River Group. The base-of-aquifer surface at test hole 8-SP-11 is interpreted to be at the top of the lower interval of firm siltstone at $610 \mathrm{ft}(4,569 \mathrm{ft}$ above the National Geodetic Vertical Datum of 1929 [NGVD 29]), although it is possible that the Brule was reached at a shallower depth.

Test hole 10-SP-11 was drilled in northern Kimball County approximately 6 miles southeast of test hole 8-SP11. At test hole 10-SP-11, the base of aquifer is interpreted at $541 \mathrm{ft}$ below land surface at the top of a $59-\mathrm{ft}$ interval of greenish-gray, well-cemented very fine grained sandstone that is interpreted to be the Fox Hills Formation. The resistivity of this unit was around $25 \mathrm{ohm}-\mathrm{m}$ and the recorded rate of penetration was very slow, characteristic of this geologic unit. At this location the Brule apparently has been completely eroded away. Approximately 1.6 miles to the northwest of test hole 10 -SP-11 is test hole 10-ANB-70, where previous researchers noted that beds below $545 \mathrm{ft}$ (4,545 ft above NGVD 29) may be older than the Ogallala. In places where the Brule has been eroded away, previous researchers interpreted the base of aquifer at the top of the Cretaceous units. The base of aquifer for test hole $10-\mathrm{SP}-11$ is interpreted at $541 \mathrm{ft}$ below land surface $(4,476 \mathrm{ft}$ above NGVD 29).

The depth to the base of aquifer determined for test holes drilled for this report were compared with the base-of-aquifer surface interpreted by previous researchers. In general, there were greater differences in the reported base-of-aquifer elevation north of Lodgepole Creek compared to areas south of Lodgepole Creek. The largest difference was noted at test hole 5-SP-11 where an Ogallala-filled paleovalley previously had been interpreted based on relatively sparse test-hole data west of 5-SP-11. The base of aquifer near test hole 5-SP-11 reported herein is approximately $230 \mathrm{ft}$ higher in elevation than 
previously interpreted. Among other test holes that are likely to have been drilled in Ogallala-filled paleovalleys, including test holes 3-SP-11, 4-SP-11, 8-SP-11, 10-SP-11, 1-CC-11, and 7-CC-11, the greatest difference in the interpreted base of aquifer was noted for test-hole 7-CC-11, northeast of Potter, Nebraska, where the base of aquifer is $180 \mathrm{ft}$ deeper than previously interpreted.

\section{References Cited}

Abraham, J.D., Cannia, J.C., Bedrosian, P.A., Johnson, M.R., Ball, L.B., and Sibray, S.S., 2012, Airborne electromagnetic mapping of the base of aquifer in areas of western Nebraska: U.S. Geological Survey Scientific Investigations Report 2011-5219, 38 p. (Also available at http://pubs.usgs. gov/sir/2011/5219/.)

Anderson, J.A., Morin, R.H., Cannia, J.C., and Williams, J.H., 2009, Geophysical log analysis of selected test holes and wells in the High Plains aquifer, central Platte River basin, Nebraska: U.S. Geological Survey Scientific Investigations Report 2009-5033, 16 p. (Also available at http://pubs.usgs. gov/sir/2009/5033/.)

Barrash, Warren, 1986, Hydrostratigraphy and hydraulic behavior of fractured formation in Sidney Draw, Cheyenne County, Nebraska: Moscow, University of Idaho, Ph.D. dissertation, 205 p., 4 pls.

Barrash, Warren, and Morin, R.H., 1987, Hydrostratigraphy and distribution of secondary permeability in the Brule Formation, Cheyenne County, Nebraska: Geological Society of America Bulletin, v. 99, p. 445-462.

Barrash, Warren, and Ralston, D.R., 1991, Analytical modeling of a fracture zone in the Brule Formation as an aquifer receiving leakage from water-table and elastic aquitards: Journal of Hydrology, v. 125, p. 1-24.

Bjorklund, L.J., 1957, Geology and ground-water resources of the Lower Lodgepole Creek drainage basin, Nebraska, with a section on The chemical quality of the water, by E.R. Jochens: U.S. Geological Survey Water-Supply Paper 1410, 76 p., 4 pls. (Also available at http://pubs.usgs.gov/ wsp/1410/report.pdf.)

Borchert, W.B., 1976, Geohydrology of the Albin and La Grange areas, southeastern Wyoming: U.S. Geological Survey Open-File Report 76-118, 72 p.

Cannia, J.C., Woodward, Duane, and Cast, L.D., 2006, Cooperative Hydrology Study (COHYST) hydrostratigraphic units and aquifer characterization report: Lincoln, Nebr., Dept. of Natural Resources, 96 p., accessed December 2010, at http://cohyst.dnr.ne.gov/document/dc012hydro aquifer_022406.pdf.
Center for Advanced Land Management Information Technologies, 2007, 2005 Nebraska land use map: Lincoln, University of Nebraska, CALMIT geospatial data, accessed December 1, 2011, at http://www.calmit.unl. edu/2005landuse/statewide.shtml.

Century Geophysical Corp., 2011, 9144 Series E logging tool: Tulsa, Okla., accessed June 21, 2011, at http://www.century-geo.info/dnn/EquipmentSales/ LoggingTools/9144LoggingTool.aspx.

Condon, S.M., 2005, Geologic studies of the Platte River, south-central Nebraska and adjacent areas-Geologic maps, subsurface study, and geologic history: U.S. Geological Survey Professional Paper 1706, $63 \mathrm{p}$.

Condra, G.E., and Reed, E.C., 1943, The geological section of Nebraska: Nebraska Geological Survey Bulletin (Conservation and Survey Division, University of Nebraska-Lincoln), v. $14,82 \mathrm{p}$.

Darton, N.H., 1903, Preliminary report on the geology and water resources of Nebraska west of the one hundred and third meridian: U.S. Geological Survey Professional Paper 17, 69 p., 43 pls. (Also available at http://pubs.usgs.gov/ pp/0017/report.pdf.)

Darton, N.H., 1905, Preliminary report on the geology and underground water resources of the central Great Plains: U.S. Geological Survey Professional Paper 32, 433 p.

Diffendal, R.F., Jr., 1982, Regional implications of the geology of the Ogallala Group (upper Tertiary) of southwestern Morrill County, Nebraska, and adjacent areas: Geological Society of America Bulletin, v. 93, p. 964-976.

Diffendal, R.F., Jr., 1990, The Sidney Gravel and Kimball Formation, supposed parts of the Ogallala Group (Neogene), are not objectively mappable units, in Gustavson, T.C., ed., Geologic framework and regional hydrology-Upper Cenozoic Blackwater Draw and Ogallala Formations, Great Plains: Austin, Tex., University of Texas, p. 23-38.

Diffendal, R.F., Jr., 1999, Deuel County test-hole logs: Lincoln, Nebr., University of Nebraska-Lincoln, Conservation and Survey Division, Nebraska Water Survey Test-Hole Report No. 25, 93 p.

Diffendal, R.F., Jr., 2000, Cheyenne County test-hole logs: Lincoln, Nebr., University of Nebraska-Lincoln, Institute of Agriculture and Natural Resources, Conservation and Survey Division, Nebraska Water Survey Test-Hole Report No. 17, 246 p.

Dugan, J.T., and Zelt, R.B., 2000, Simulation and analysis of soil-water conditions in the Great Plains and adjacent areas, central United States, 1951-80: U.S. Geological Survey Water Supply Paper 2427, 81 p. 
Evans, J.E., and Terry, D.O., Jr., 1994, The significance of incision and fluvial sedimentation in the basal White River Group (Eocene-Oligocene), Badlands of South Dakota, U.S.A.: Sedimentary Geology, v. 90, p. 137-152.

Fenneman, N.M., 1946, Physiographic divisions of the conterminous United States: U.S. Geological Survey Special Map Series, scale 1:7,000,000.

Gutentag, E.D., Heimes, F.J., Krothe, N.C., Luckey, R.R., and Weeks, J.B., 1984, Geohydrology of the High Plains aquifer in parts of Colorado, Nebraska, New Mexico, Oklahoma, South Dakota, Texas, and Wyoming: U.S. Geological Survey Professional Paper 1400-B, 63 p. (Also available at http://pubs.usgs.gov/pp/1400b/report.pdf.)

Helland, P.E., and Diffendal, R.F., Jr., 1993, Probable glacial climatic conditions in source areas during deposition of parts of the Ash Hollow Formation, Ogallala Group (Late Tertiary), of western Nebraska: American Journal of Science, v. 293, p. 744-757.

High Plains Regional Climate Center, 2013, Sidney 6 NNW, National climatic data center, Monthly climate summary: accessed December 23, 2013, at http://www.hprcc.unl.edu/ cgi-bin/cli_perl_lib/cliMAIN.pl?ne7830.

Houston, N.A., Gonzales-Bradford, S.L., Flynn, A.T., Qi, S.L., Peterson, S.M., Stanton, J.S., Ryter, D.W., Sohl, T.L., and Senay, G.B., 2013, Geodatabase compilation of hydrogeologic, remote sensing, and water-budget-component data for the High Plains aquifer, 2011: U.S. Geological Survey Data Series 777, 12 p. (Also available at http://pubs.usgs.gov/ $d s / 777 /$ )

Irons, T.P., Hobza, C.M., Steele, G.V., Abraham, J.D., Cannia, J.C., and Woodward, D.D., 2012, Quantification of aquifer properties with surface nuclear magnetic resonance in the Platte River valley, central Nebraska, using a novel inversion method: U.S. Geological Survey Scientific Investigations Report 2012-5189, 50 p. (Also available at http:// pubs.usgs.gov/sir/2012/5189/sir2012-5189.pdf.)

Keys, W.S., 1990, Borehole geophysics applied to groundwater investigations: U.S. Geological Survey Techniques of Water-Resources Investigations, book 2, chap. E2, p. 48-83. (Also available at http://pubs.usgs.gov/twri/twri2-e2/.)

Korus, J.T., and Joeckel, R.M., 2011, Generalized geologic and hydrostratigraphic framework of Nebraska 2011, ver. 2: Lincoln, Conservation and Survey Division, University of Nebraska-Lincoln, Geologic Maps and Charts (GMC) 38.

Lowry, M.E., 1966, The White River Formation as an aquifer in southeastern Wyoming and adjacent parts of Nebraska and Colorado: U.S. Geological Survey Professional Paper 550-D, p. 217-222.
Luckey, R.R., Gutentag, E.D., Heimes, F.J., and Weeks, J.B., 1988, Effects of future ground-water pumpage on the High Plains Aquifer in parts of Colorado, Kansas, Nebraska, New Mexico, Oklahoma, South Dakota, Texas, and Wyoming: U.S. Geological Survey Professional Paper 1400-E, 44 p. (Also available at http://pubs.er.usgs.gov/publication/ pp1400E.)

Luckey, R.R., and Cannia, J.C., 2006, Ground water flow model of the western model unit of the Nebraska Cooperative Hydrology Study (COHYST) area: Lincoln, Nebr., Nebraska Department of Natural Resources, 63 p., accessed May 2013, at http://cohyst.dnr.ne.gov/adobe/dc012WMU_ GFMR_060519.pdf.

McDonald, M.G., and Harbaugh, A.W., 1988, A modular three-dimensional finite difference ground-water flow model: U.S. Geological Survey Techniques of WaterResource Investigation, book 6, chap. A1, 586 p.

McGuire, V.L., 2013, Water-level and storage changes in the High Plains aquifer, predevelopment to 2011 and 2009-11: U.S. Geological Survey Scientific Investigations Report 2012-5291, 15 p. (Also available at http://pubs.usgs.gov/ sir/2012/5291/.)

Meinzer, O.E., 1923, The occurrence of ground water in the United States, with a discussion of principles: U.S. Geological Survey Water-Supply Paper 489, 321 p.

Mount Sopris Instruments, 2011, Poly Series tools: Denver, Colo., accessed Dec. 1, 2011, at http://www.mountsopris. com/index.php/products/category/polyseriestools.

Ostdiek, Amy, 2009, The integrated management planning process: Lincoln, Nebr., Nebraska Dept. of Natural Resources, Water Matters, no. 1, 4 p., accessed November 3, 2010, at http://www.dnr.ne.gov/iwm/watermatters -1 .

Qi, S.L., and Christenson, Scott, 2010, Assessing groundwater availability in the High Plains Aquifer in parts of Colorado, Kansas, Nebraska, New Mexico, Oklahoma, South Dakota, Texas, and Wyoming: U.S. Geological Survey Fact Sheet 2010-3008, 4 p. (Also available at http://pubs.usgs.gov/ fs/2010/3008/.)

Rydlund, P.H., Jr., and Densmore, B.K., 2012, Methods of practice and guidelines for using survey-grade global navigation satellite systems (GNSS) to establish vertical datum in the United States Geological Survey: U.S. Geological Survey Techniques and Methods, book 11, chap. D1, 102 p. with appendixes. (Also available at http://pubs.usgs. gov/tm/11d1/tm11-D1.pdf.) 
Sibray, S.S., and Zhang, Y.K., 1994, Three-dimensional modeling of hydraulic behavior of a highly conductive secondary permeability zone in the Brule Formation, in Warner, J.W., and van der Heijde, Paul, eds., Proceedings of 1994 Groundwater Modeling Conference, Fort Collins, Colo., August 10-12, 1994: Fort Collins, Colorado State University, p. $445-452$.

Smith, F.A., 2000a, Banner County test-hole logs: Lincoln, Nebr., University of Nebraska-Lincoln, Conservation and Survey Division, Nebraska Water Survey Test-Hole Report No. 4, 47 p.

Smith, F.A., 2000b, Kimball County test-hole logs: Lincoln, Nebr., University of Nebraska-Lincoln, Conservation and Survey Division, Nebraska Water Survey Test-Hole Report No. 53, 153 p.

South Platte Natural Resources District, 2009, Integrated management plan, jointly developed by the South Platte Natural Resources District and the Nebraska Department of Natural Resources: Sidney, Nebr., South Platte Natural Resources District, accessed November 7, 2013, at http://www.spnrd. org/PDFs/Rules_Regs_Programs/IMP\%20September\%20 14,\%202009.pdf.

Stanton, G.P., Kress, W.H., Teeple, A.P., Greenslate, M.I., and Clark, A.K., 2007, Geophysical analysis of the Salmon Peak Formation near Amistad Reservoir Dam, Val Verde County, Texas, and Coahuila, Mexico, March 2006, to aid in piezometer placement: U.S. Geological Survey Scientific Investigations Report 2007-5143, 70 p. (Also available at http://pubs.usgs.gov/sir/2007/5143/.)

Stanton, J.S., Qi, S.L., Ryter, D.W., Falk, S.E., Houston, N.A., Peterson, S.M., Westenbroek, S.M., and Christenson, S.C., 2011, Selected approaches to estimate water-budget components of the High Plains, 1940 through 1949 and 2000 through 2009: U.S. Geological Survey Scientific Investigations Report 2011-5183, 79 p.

Steele, G.V., Sibray, S.S., and Quandt, K.A., 2007, Evaluation of ground water near Sidney, western Nebraska, 2004-05: U.S. Geological Survey Scientific Investigations Report 2007-5086, 54 p. (Also available at http://pubs.usgs.gov/ $\operatorname{sir} / 2007 / 5086 /$.
Swinehart, J.B., and Diffendal, R.F., 1989, Geology, in Bleed, A.S., and Flowerday, C.A., eds., An atlas of the Sand Hills: Lincoln, Nebr., University of Nebraska, Conservation and Survey Division, Resource Atlas, no. 5a, p. 29-42.

Swinehart, J.B., and Diffendal, R.F., Jr., 1997, Geologic map of the Scottsbluff $1^{\circ} \times 2^{\circ}$ quadrangle, Nebraska and Colorado: U.S. Geological Survey Miscellaneous Investigations Series Map I-12545, scale 1:250,000.

Swinehart, J.B., Souders, V.L., DeGraw, H.M., and Diffendal, R.F., Jr., 1985, Cenozoic paleogeography of western Nebraska, in Flores, R.M., and Kaplan, S.S., eds., Cenozoic paleogeography of the west-central United States, Denver, Colo., Rocky Mountain Paleogeography Symposium 3: Tulsa, Society of Economic Paleontologists and Mineralogists, p. 209-229.

Terry, D.O., Jr., and Evans, J.E., 1994, Pedogenesis and paleoclimatic implications of the Chamberlain Pass Formation, basal White River Group, badlands of South Dakota: Paleogeography, Paleoclimatology, Paleoecology, v. 110, p. 197-215.

Trimble Navigation Limited, 2009, Trimble R8 GNSS Receiver User Guide (Revision A): Sunnyvale, Calif., Trimble Navigation Limited, 78 p., accessed November 5, 2013, at http://trl.trimble.com/docushare/dsweb/Get/ Document-666214/R8-R6-R4-5800M3_v411A_UserGuide. $p d f$.

University of Nebraska-Lincoln, Conservation and Survey Division, 2013, Test-hole database: Lincoln, Nebr., Conservation and Survey Division digital data, accessed November 12, 2013, at http://snr.unl.edu/data/geologysoils/ NebraskaTestHole/NebraskaTestHoleIntro.asp.

U.S. Geological Survey Crustal Geophysics and Geochemistry Science Center, 2014, Airborne geophysical surveys conducted in western Nebraska, 2010 - Contractor reports and data: U.S. Geological Survey Open-File Report 2013-1268, 4 p., http://dx.doi.org/10.3133/ofr20131268. 
Figures 3-30 


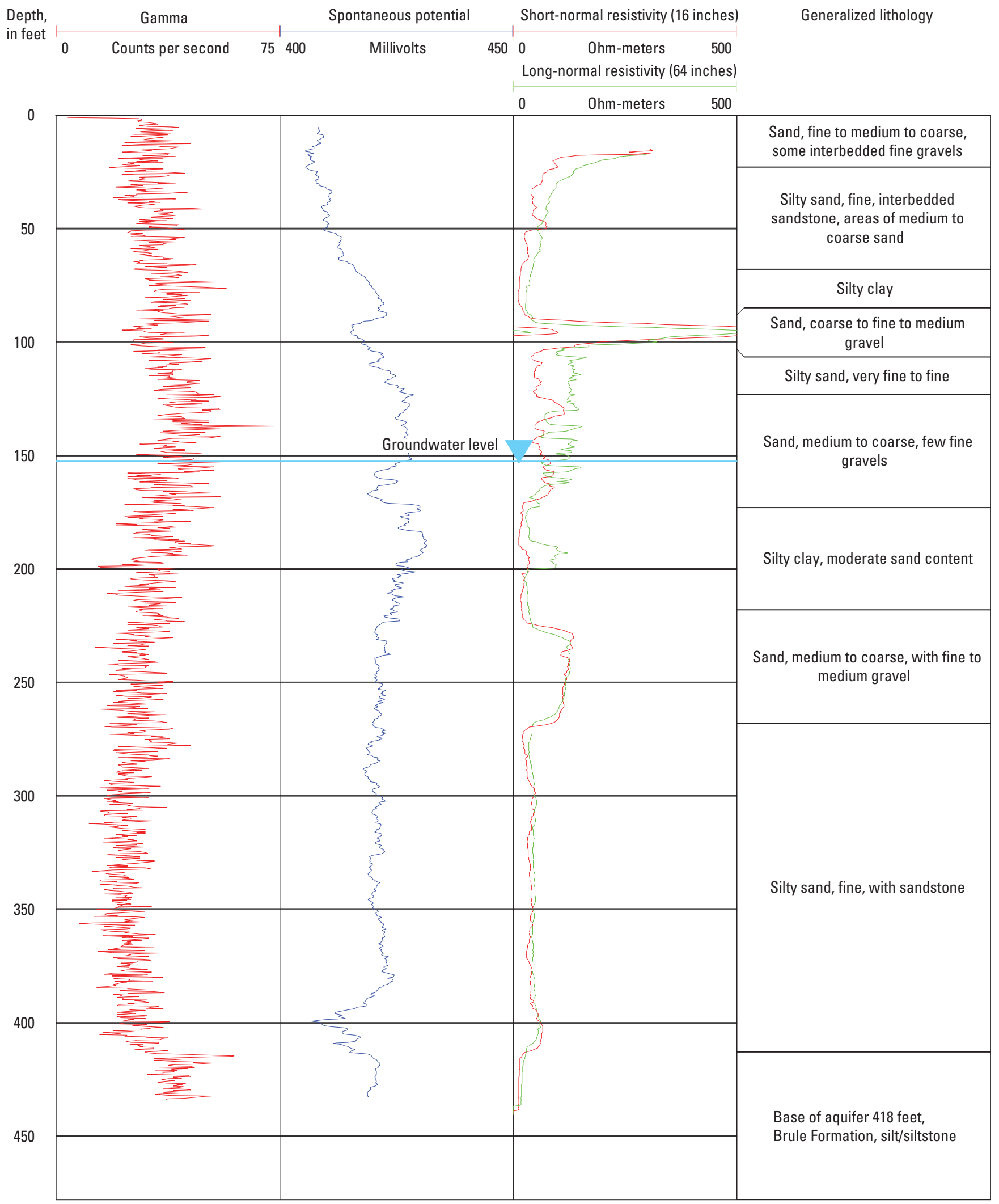

Figure 3. Composite of generalized lithologic description and geophysical logs for test hole 2-SP-11, Kimball County, Nebraska. 


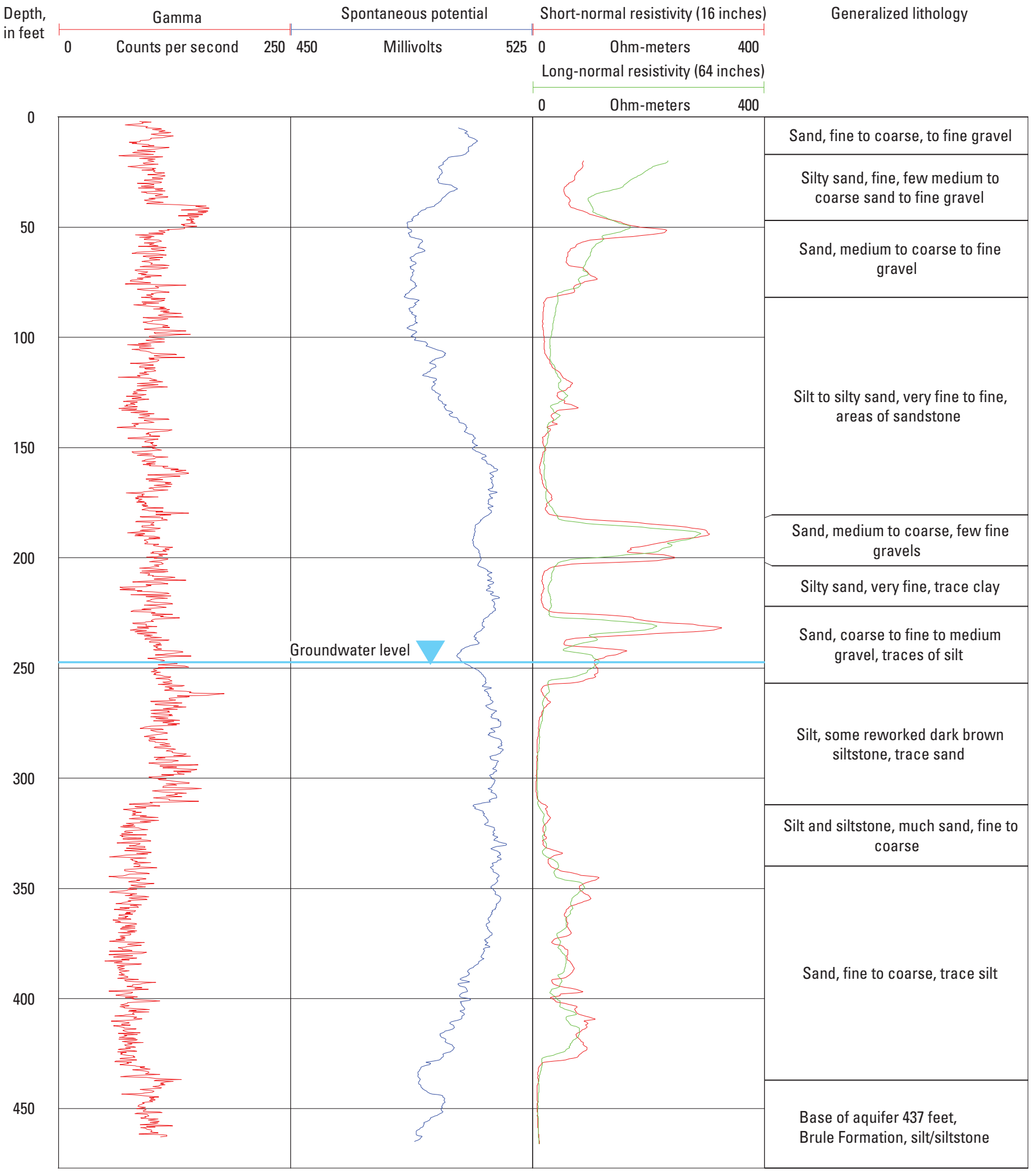

Figure 4. Composite of generalized lithologic description and geophysical logs for test hole 3-SP-11, Kimball County, Nebraska. 


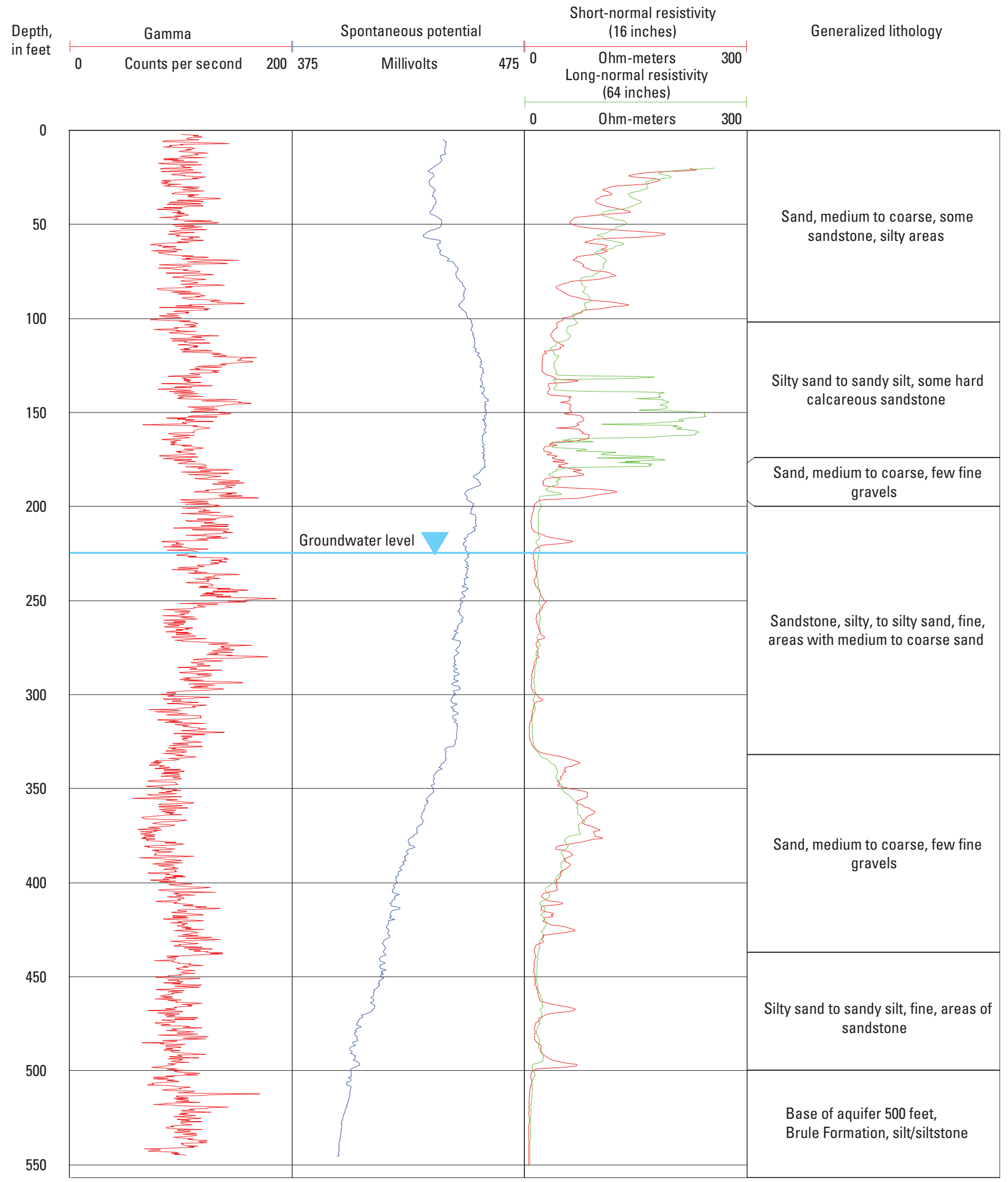

Figure 5. Composite of generalized lithologic description and geophysical logs for test hole 4-SP-11, Kimball County, Nebraska. 


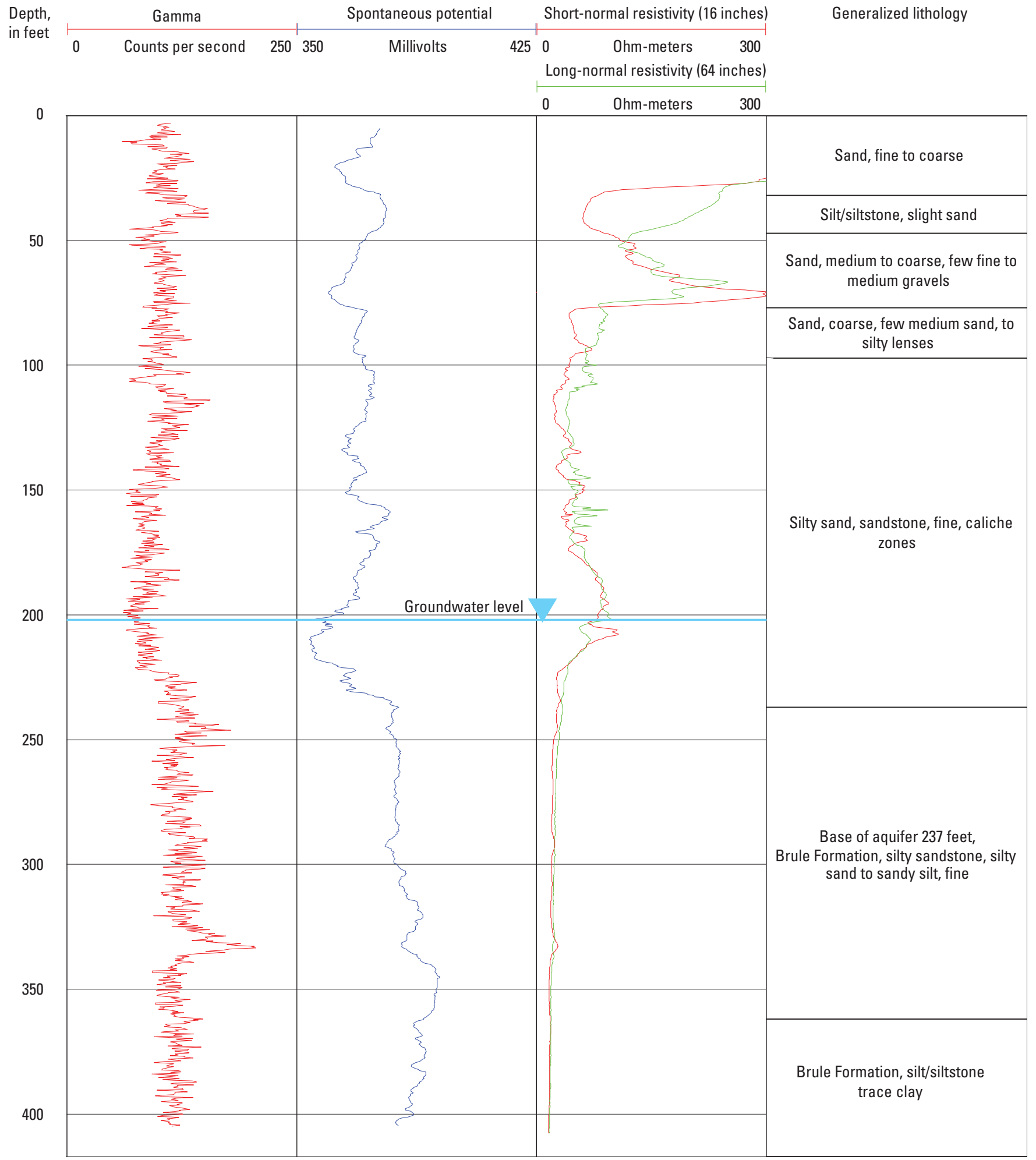

Figure 6. Composite of generalized lithologic description and geophysical logs for test hole 5-SP-11, Kimball County, Nebraska. 
22 Hydrostratigraphic Interpretation of Test-Hole and Borehole Geophysical Data, Nebraska, 2011-12

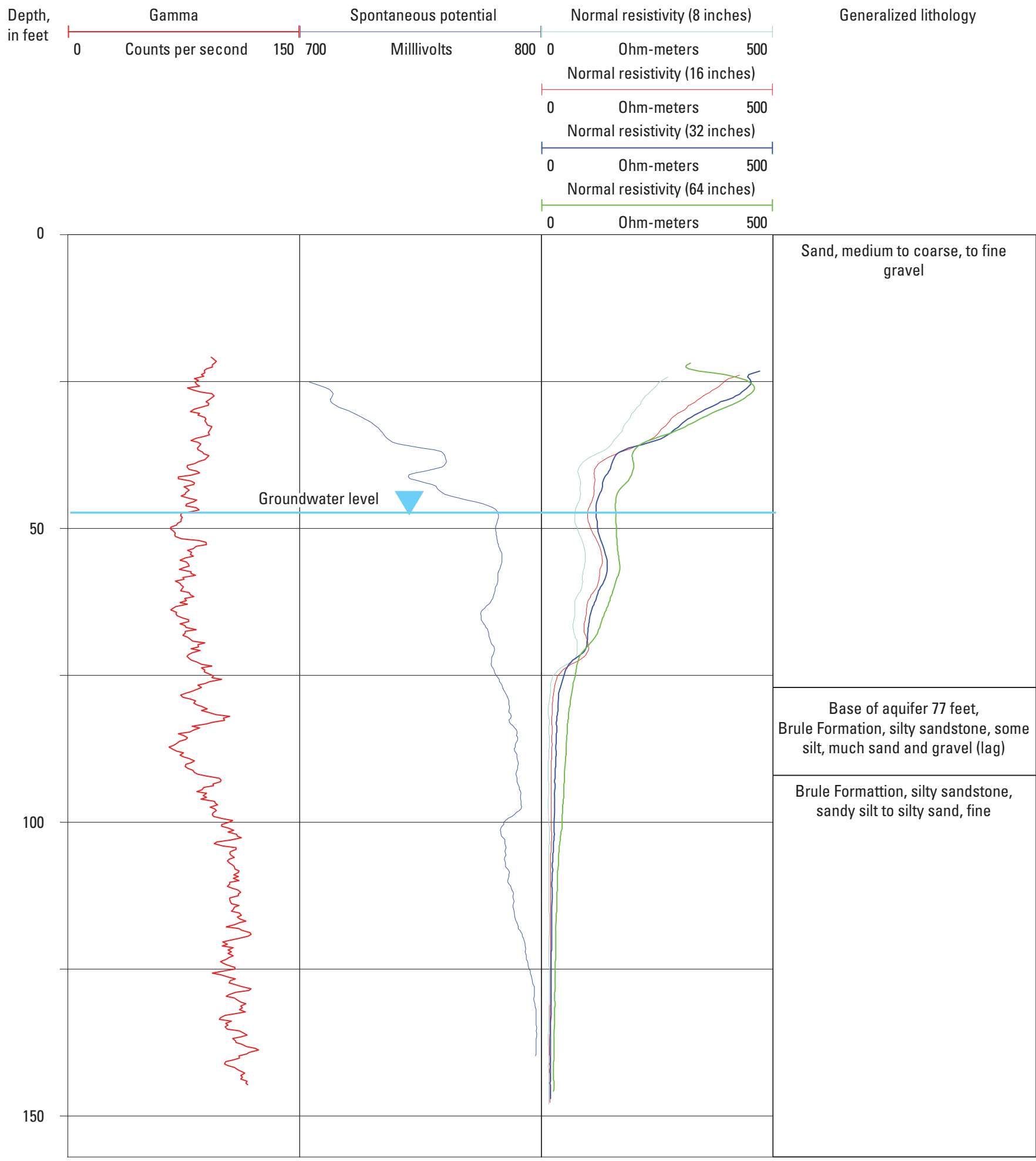

Figure 7. Composite of generalized lithologic description and geophysical logs for test hole 6-SP-11, Kimball County, Nebraska. 


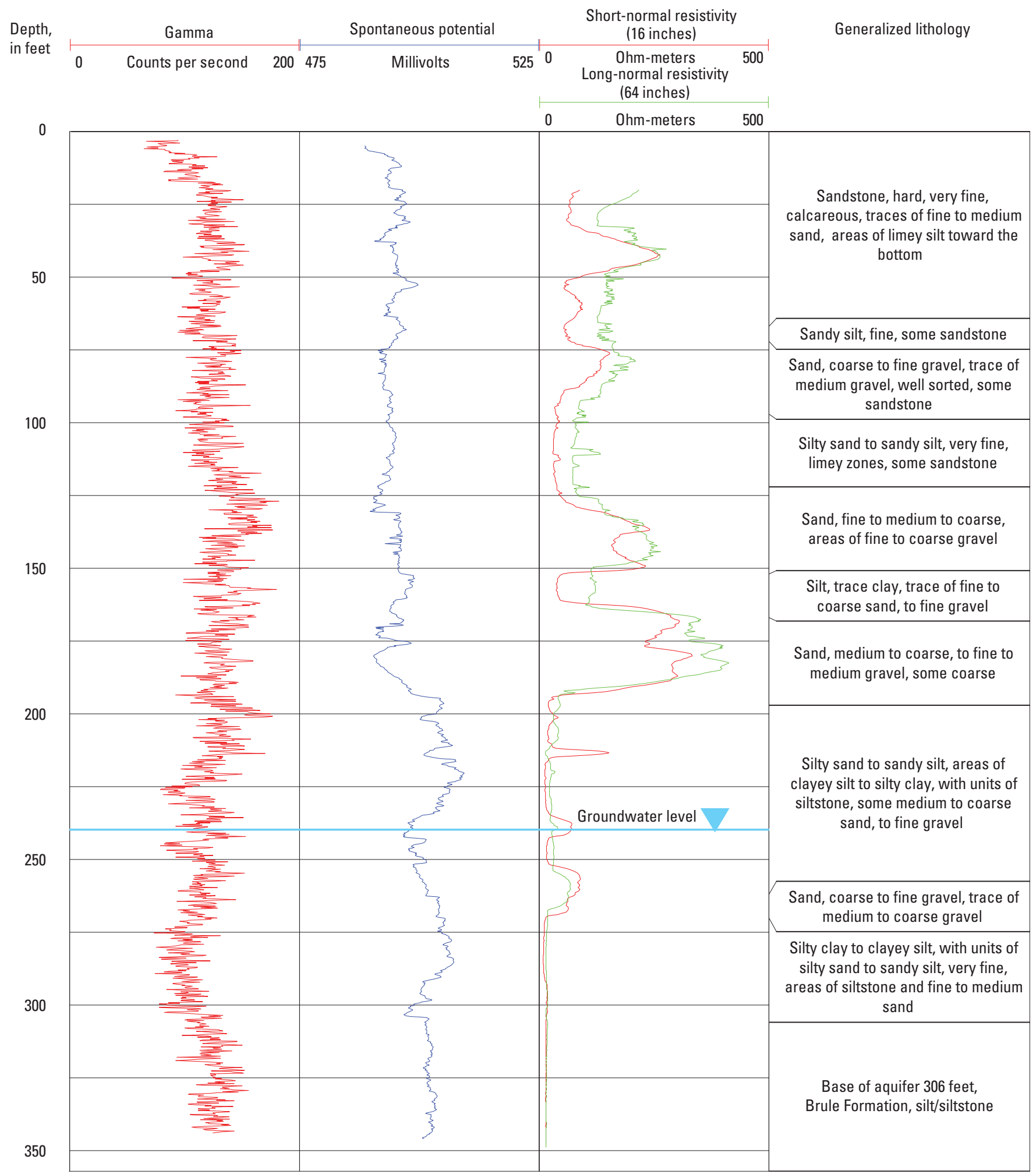

Figure 8. Composite of generalized lithologic description and geophysical logs for test hole 7-SP-11, Kimball County, Nebraska. 


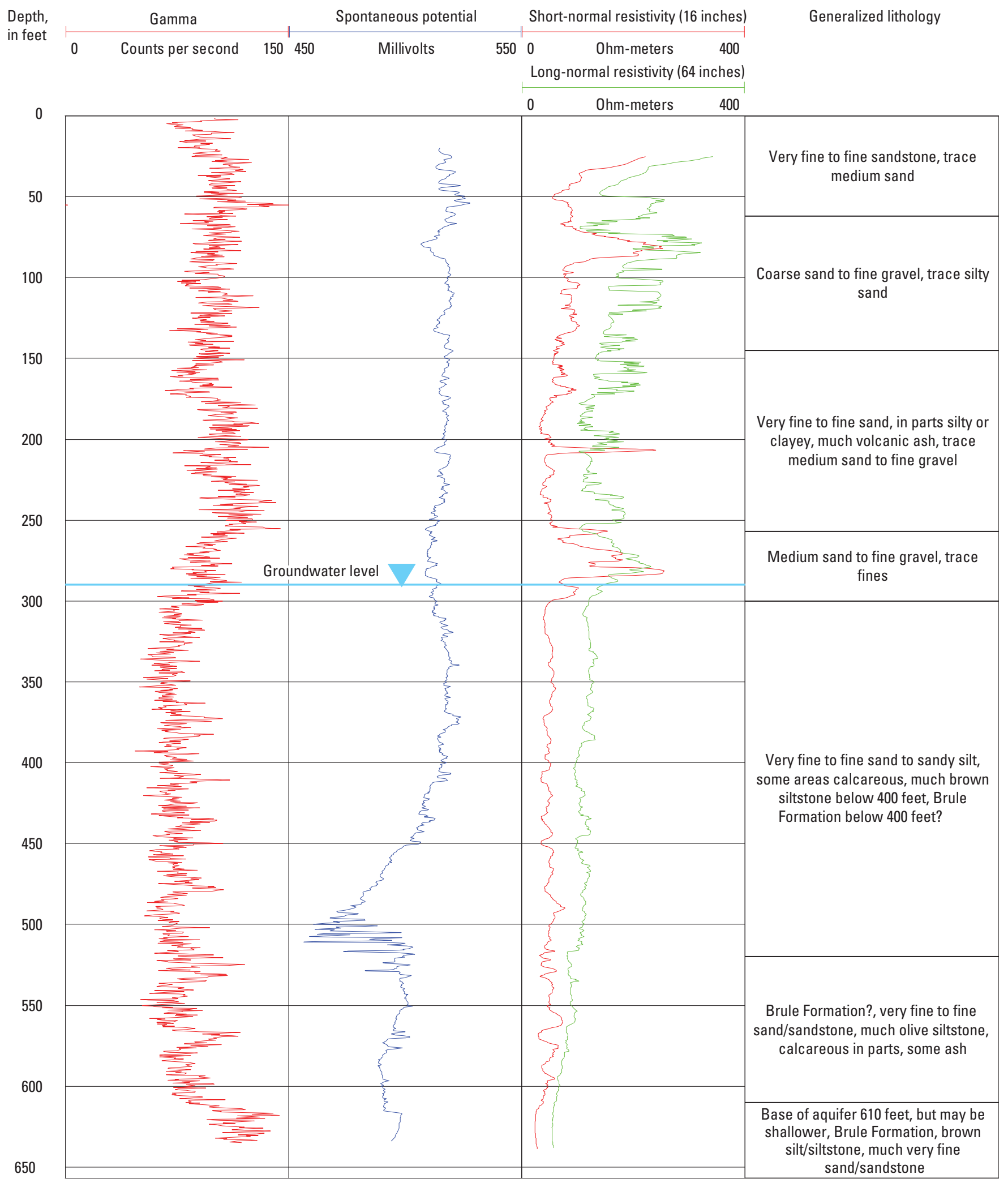

Figure 9. Composite of generalized lithologic description and geophysical logs for test hole 8-SP-11, Kimball County, Nebraska. 


\begin{tabular}{|c|c|c|c|c|c|c|c|c|}
\hline & \multicolumn{2}{|r|}{ Gamma } & & \multicolumn{2}{|c|}{ Spontaneous potential } & \multicolumn{3}{|c|}{ Short-normal resistivity (16 inches) } \\
\hline & \multirow[t]{2}{*}{0} & & 250 & \multirow{2}{*}{ Millivolts } & \multirow[t]{2}{*}{525} & 0 & Ohm-meters & 300 \\
\hline & & & & & & \multicolumn{3}{|c|}{ Long-normal resistivity (64 inches) } \\
\hline $\begin{array}{l}\text { Depth } \\
\text { in, feet }\end{array}$ & 0 & Counts per second & & & & & & Ohm-meters $\quad 300$ \\
\hline
\end{tabular}

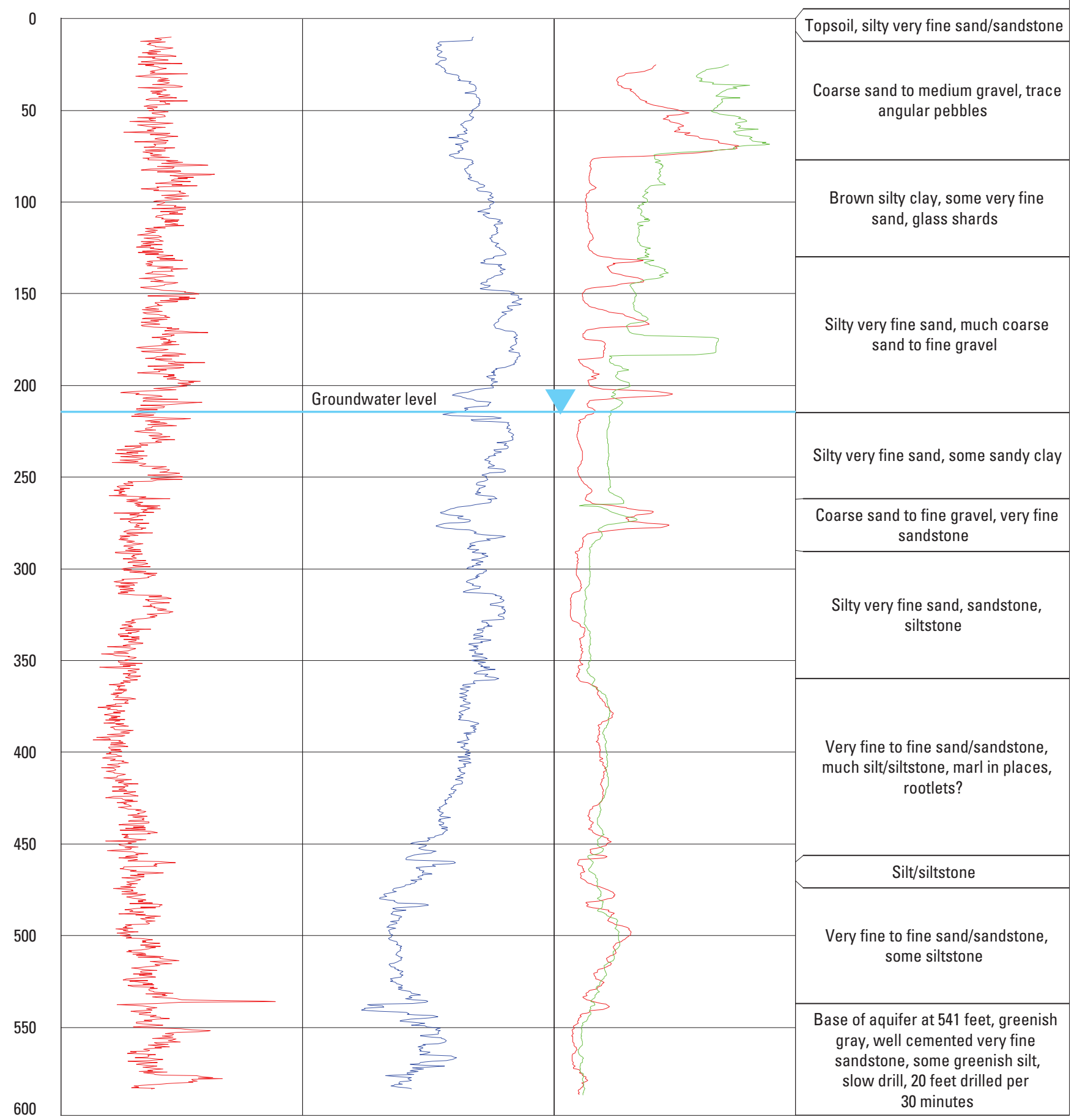

Figure 10. Composite of generalized lithologic description and geophysical logs for test hole 10-SP-11, Kimball County, Nebraska. 


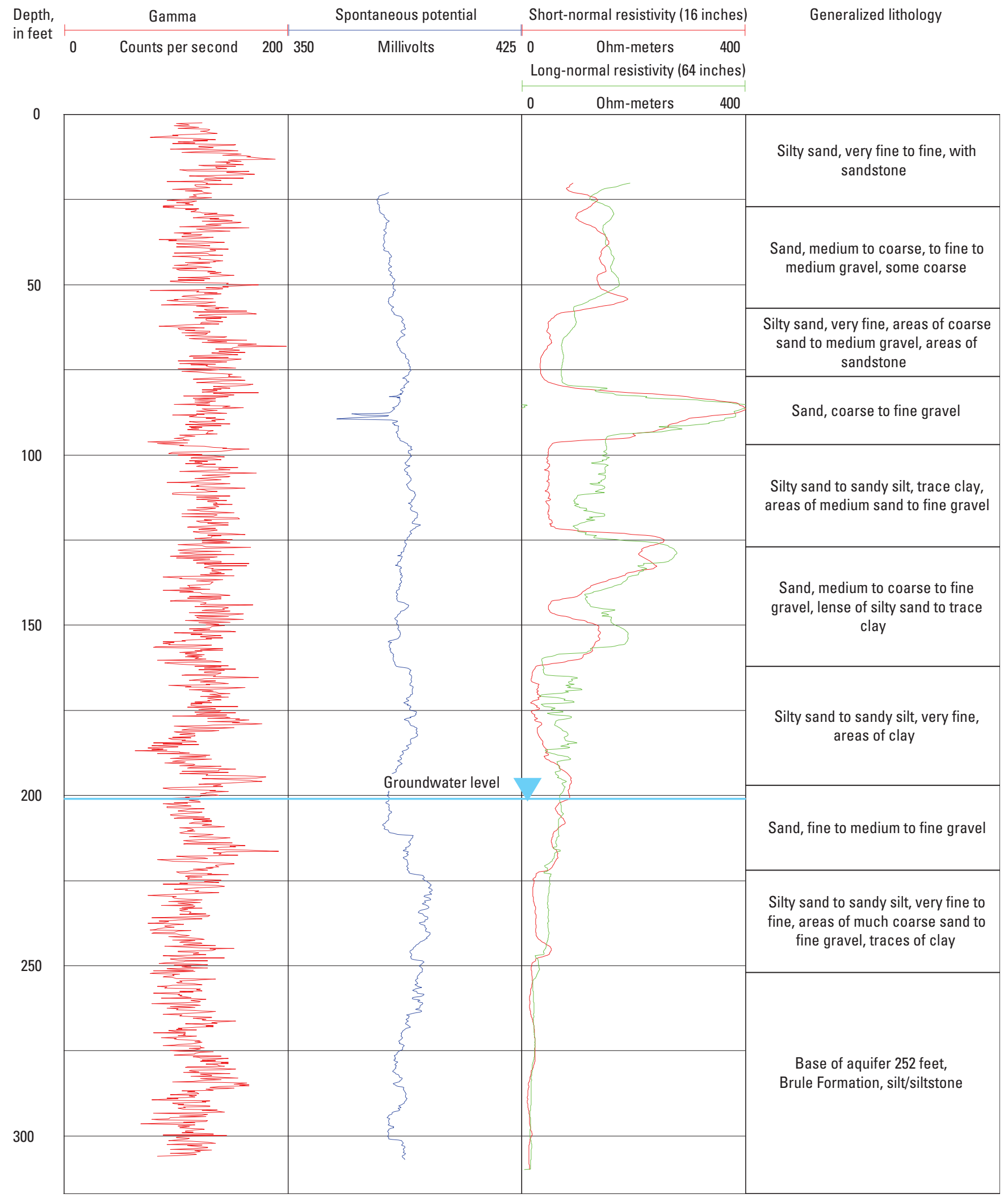

Figure 11. Composite of generalized lithologic description and geophysical logs for test hole 11-SP-11, Kimball County, Nebraska. 


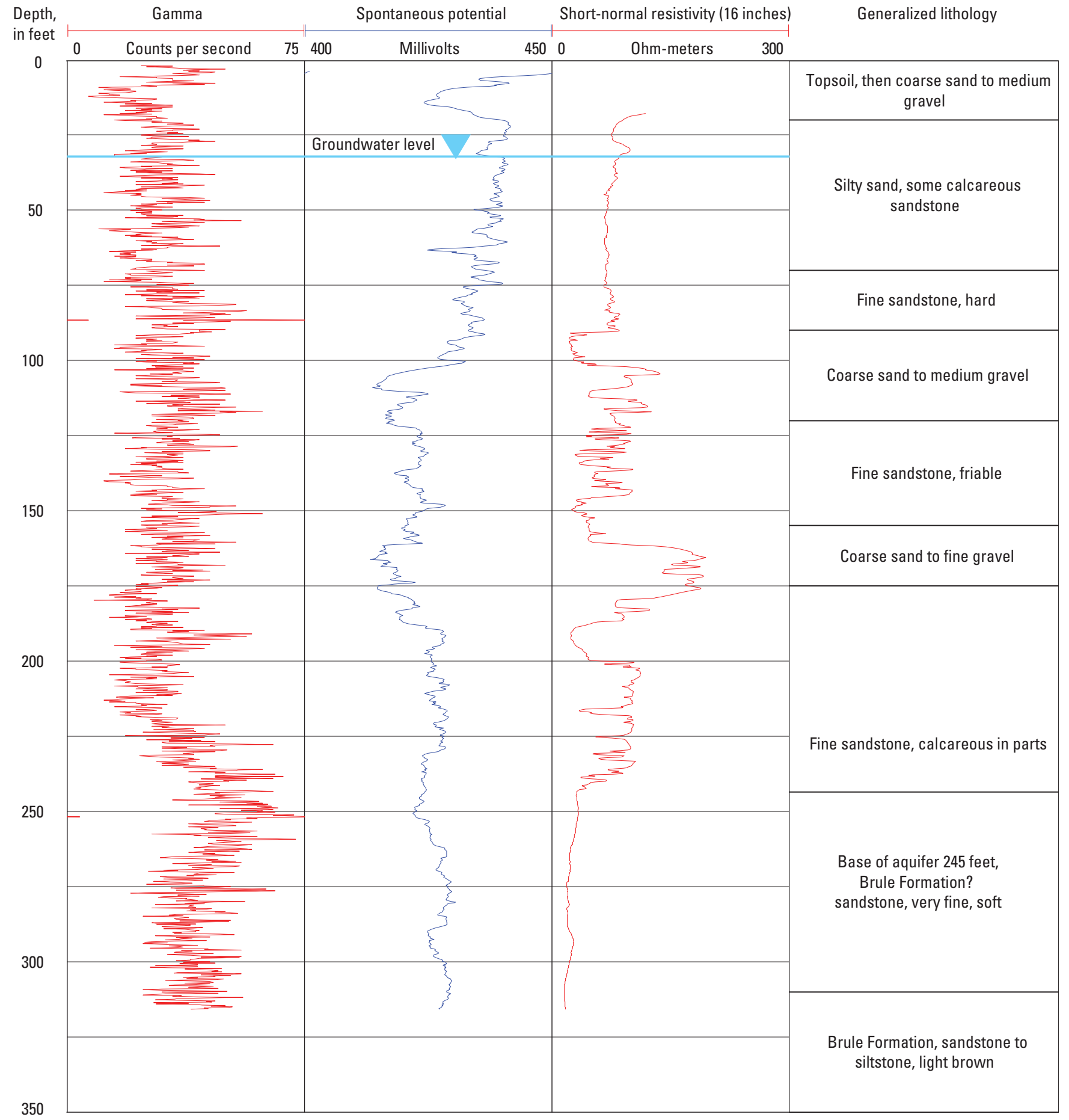

Figure 12. Composite of generalized lithologic description and geophysical logs for test hole 1-CC-11, Cheyenne County, Nebraska. 


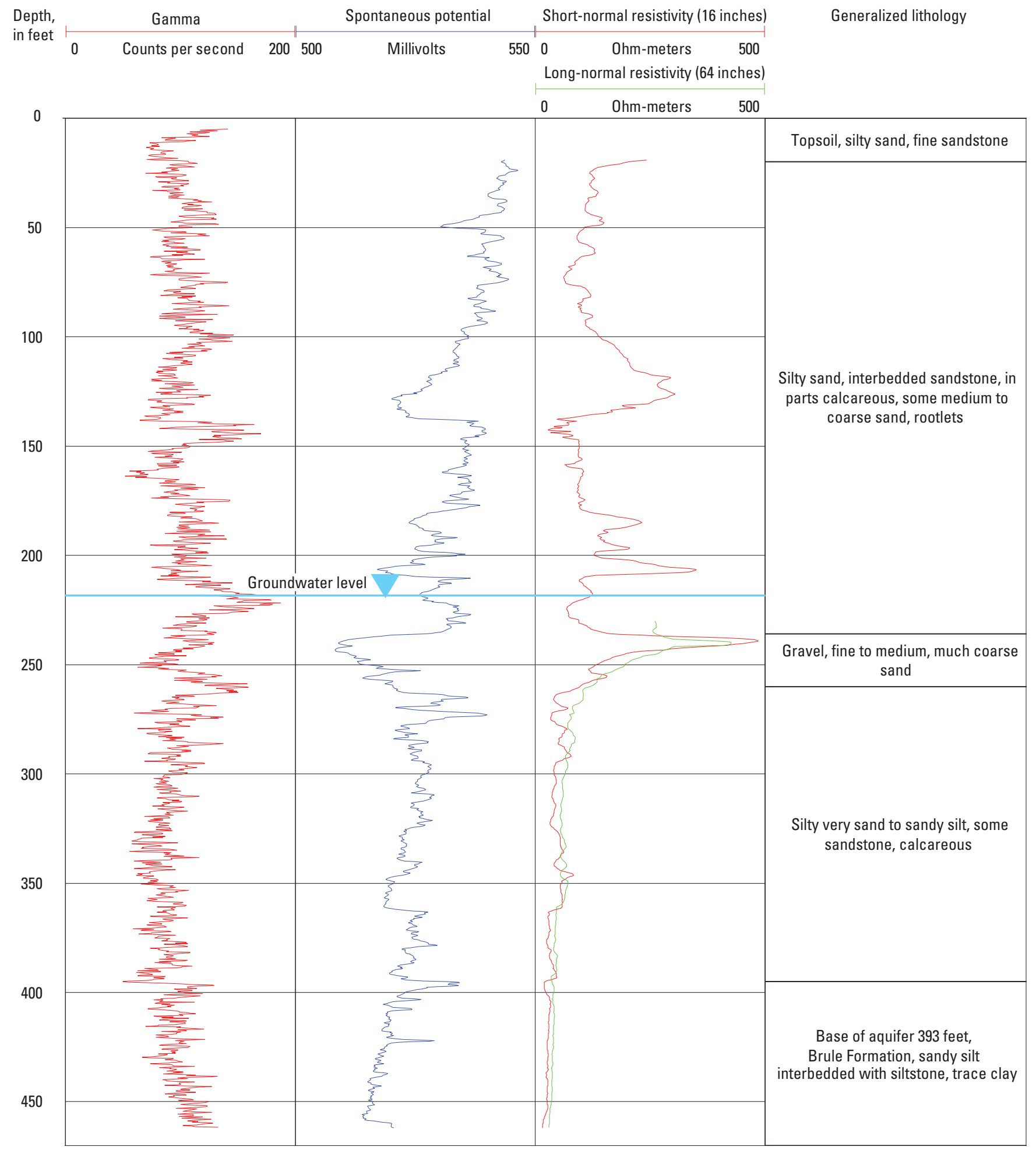

Figure 13. Composite of generalized lithologic description and geophysical logs for test hole 2-CC-11, Cheyenne County, Nebraska. 


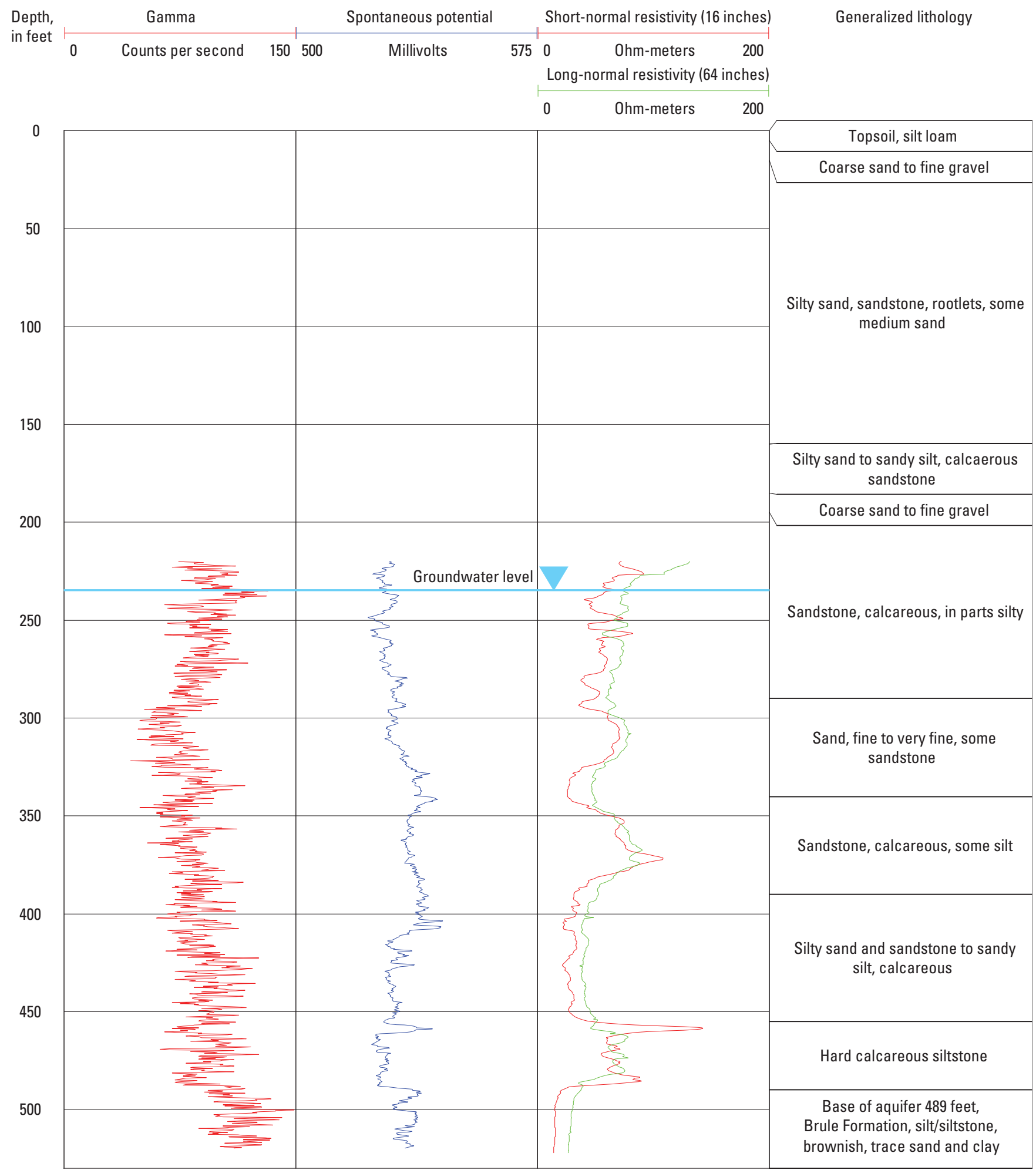

Figure 14. Composite of generalized lithologic description and geophysical logs for test hole 3-CC-11, Cheyenne County, Nebraska. 


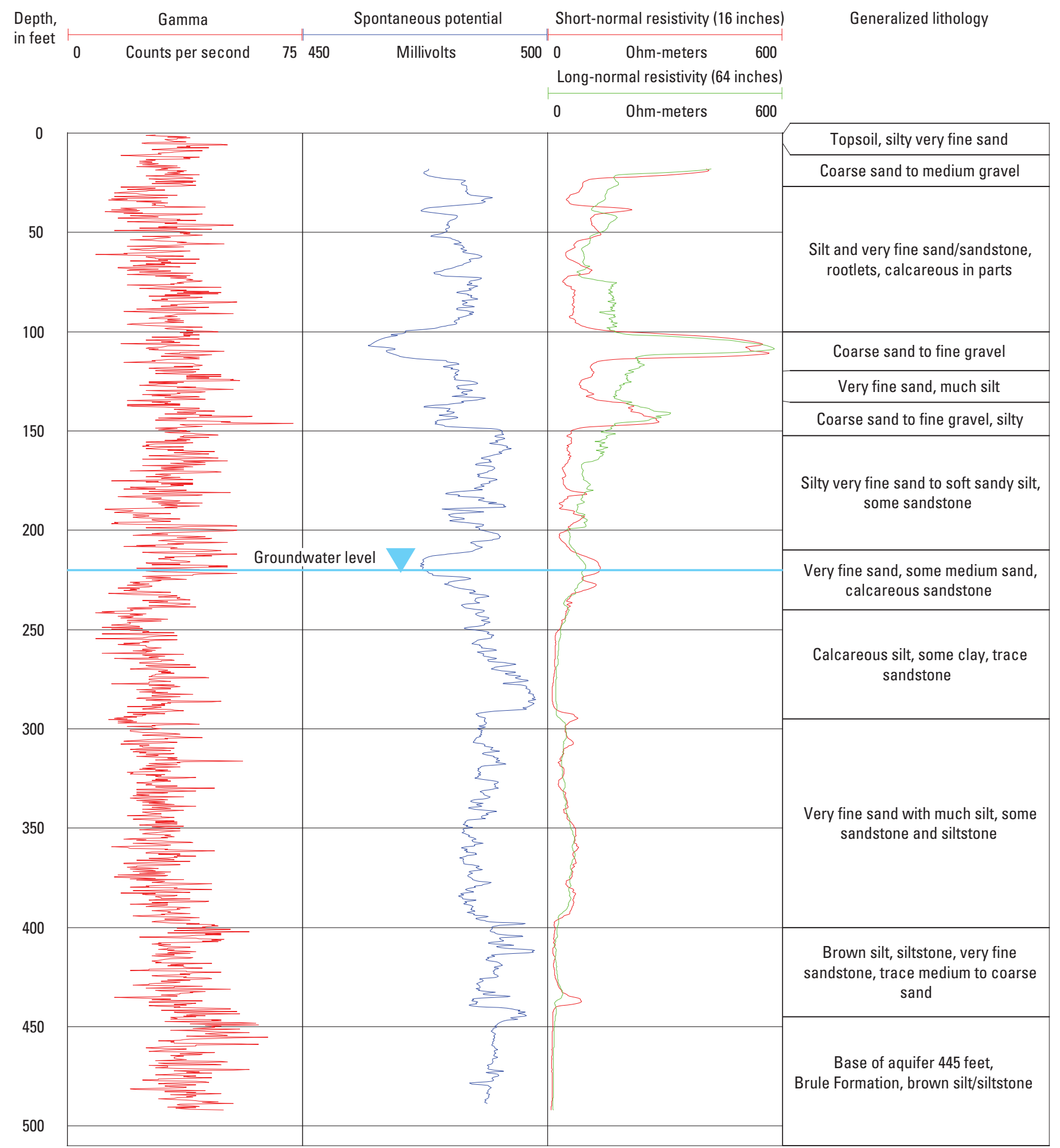

Figure 15. Composite of generalized lithologic description and geophysical logs for test hole 4-CC-11, Cheyenne County, Nebraska. 


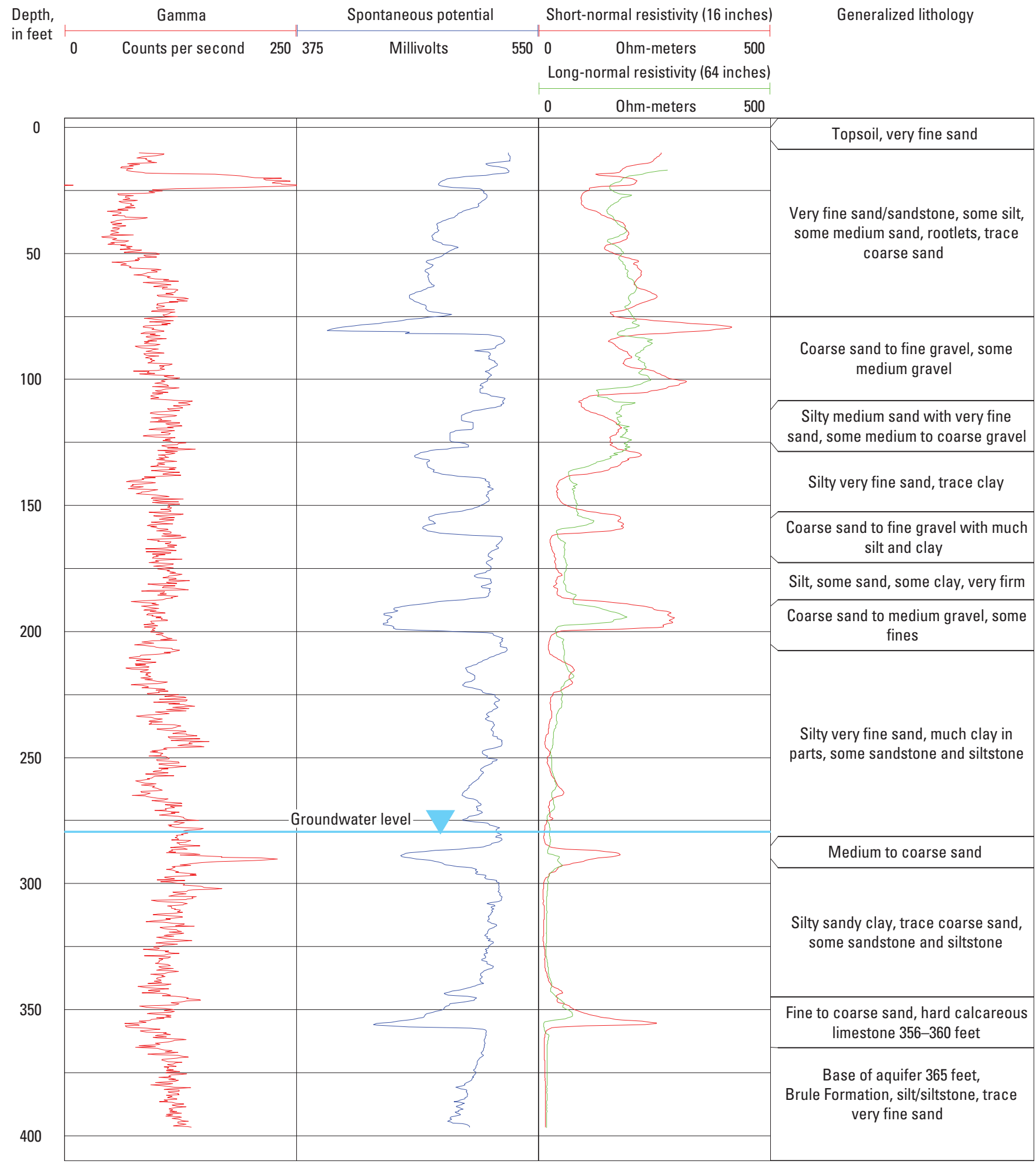

Figure 16. Composite of generalized lithologic description and geophysical logs for test hole 5-CC-11, Cheyenne County, Nebraska. 


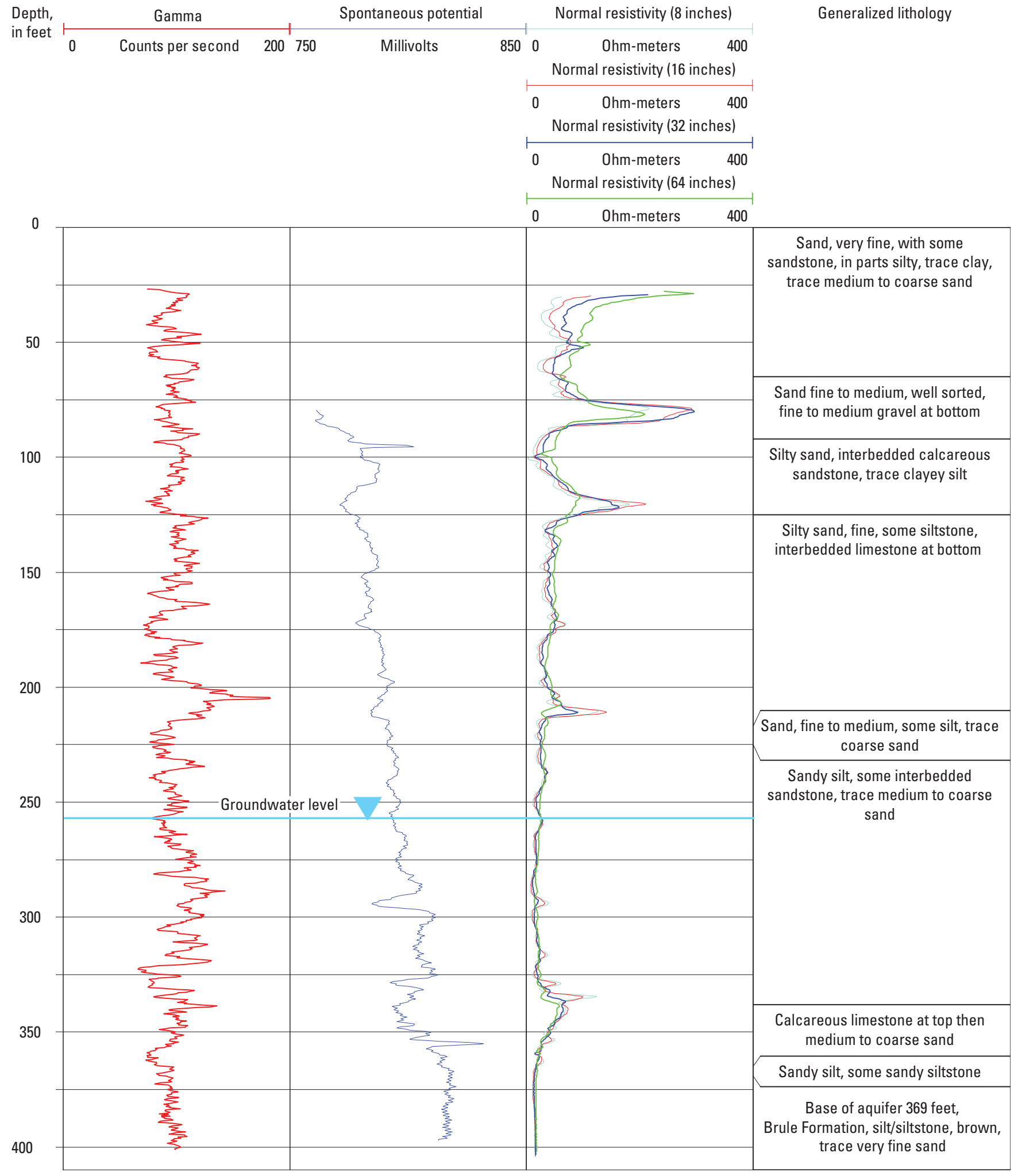

Figure 17. Composite of generalized lithologic description and geophysical logs for test hole 6-CC-11, Cheyenne County, Nebraska. 


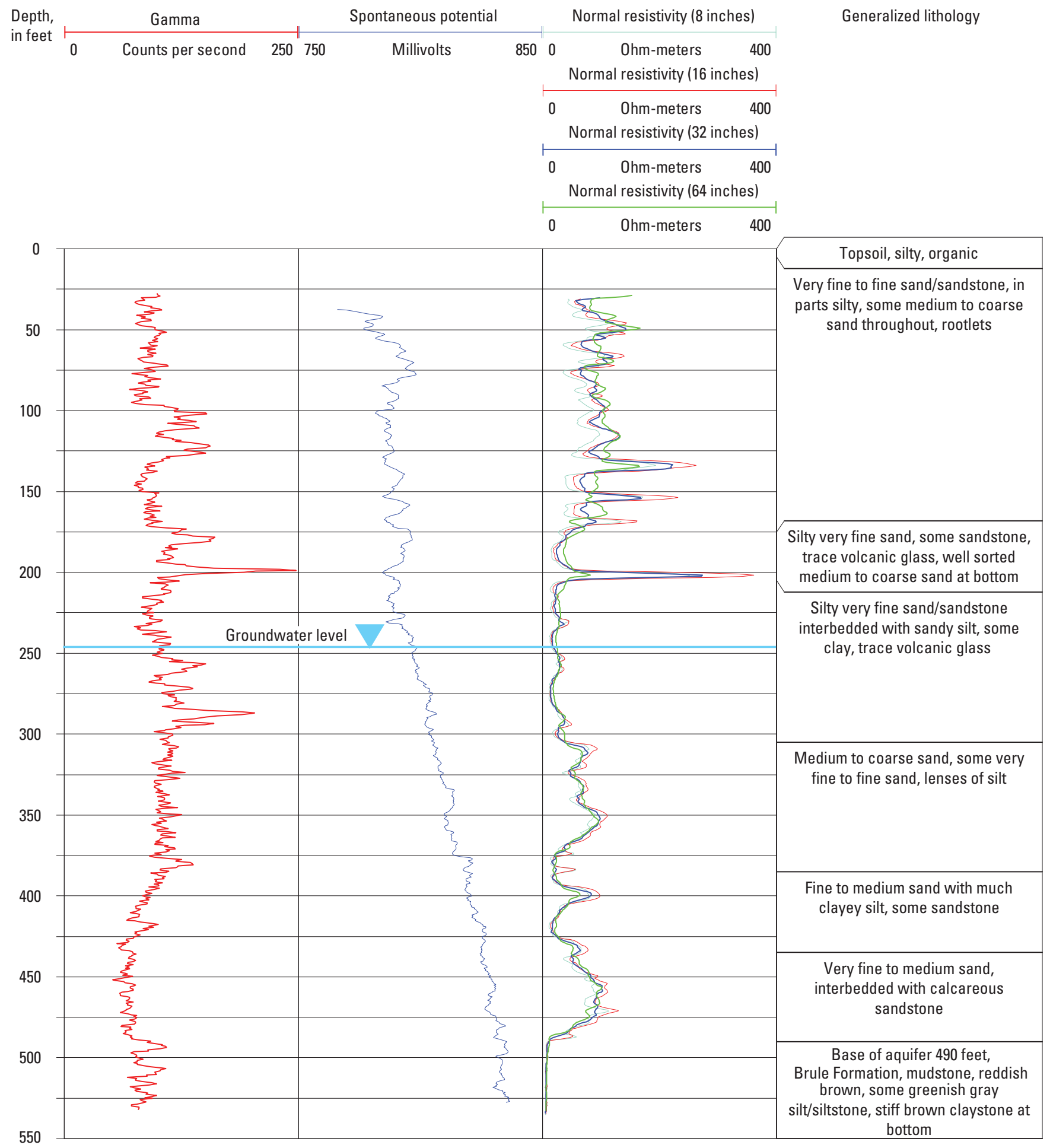

Figure 18. Composite of generalized lithologic description and geophysical logs for test hole 7-CC-11, Cheyenne County, Nebraska. 


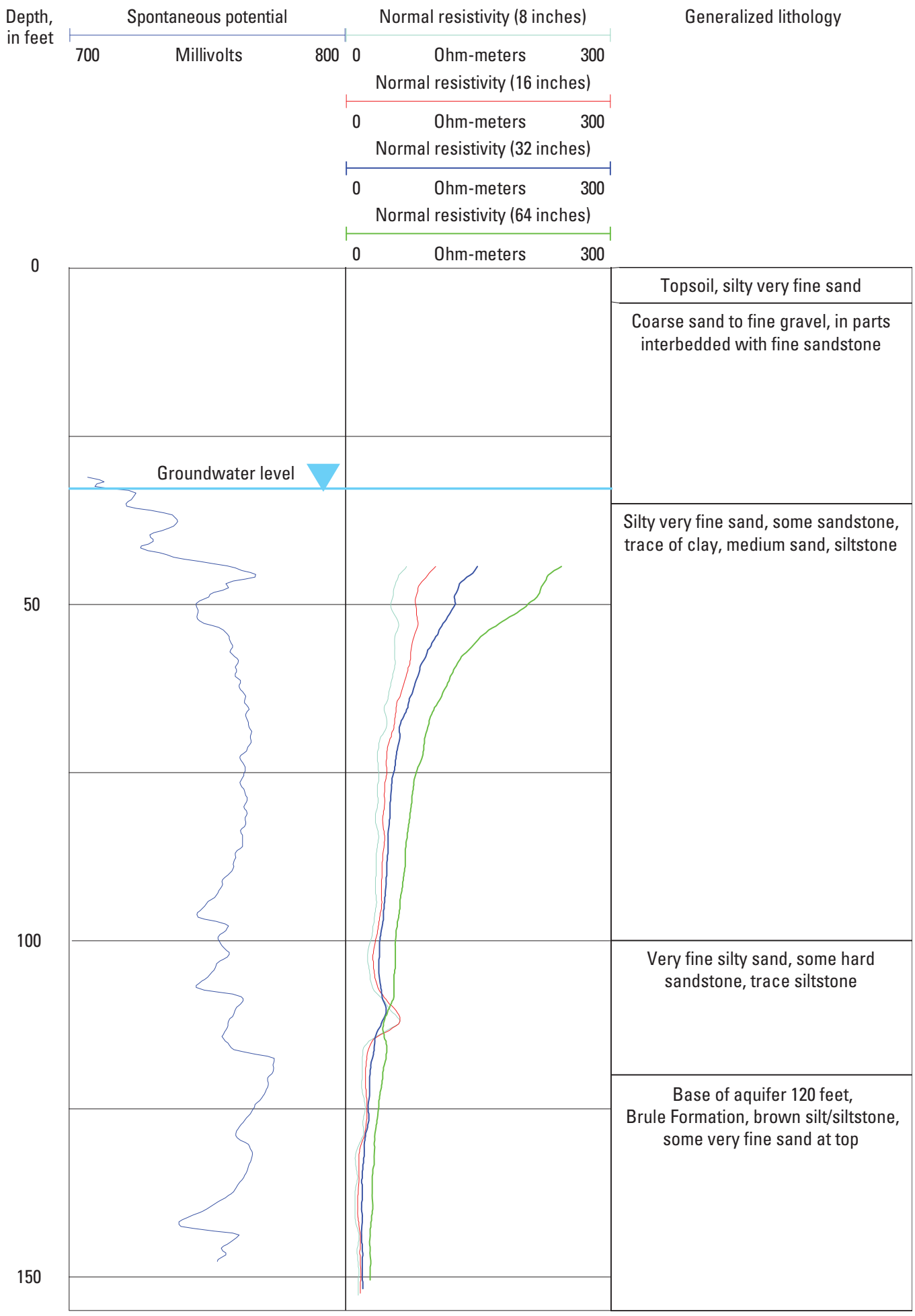

Figure 19. Composite of generalized lithologic description and geophysical logs for test hole 8-CC-11, Cheyenne County, Nebraska. 


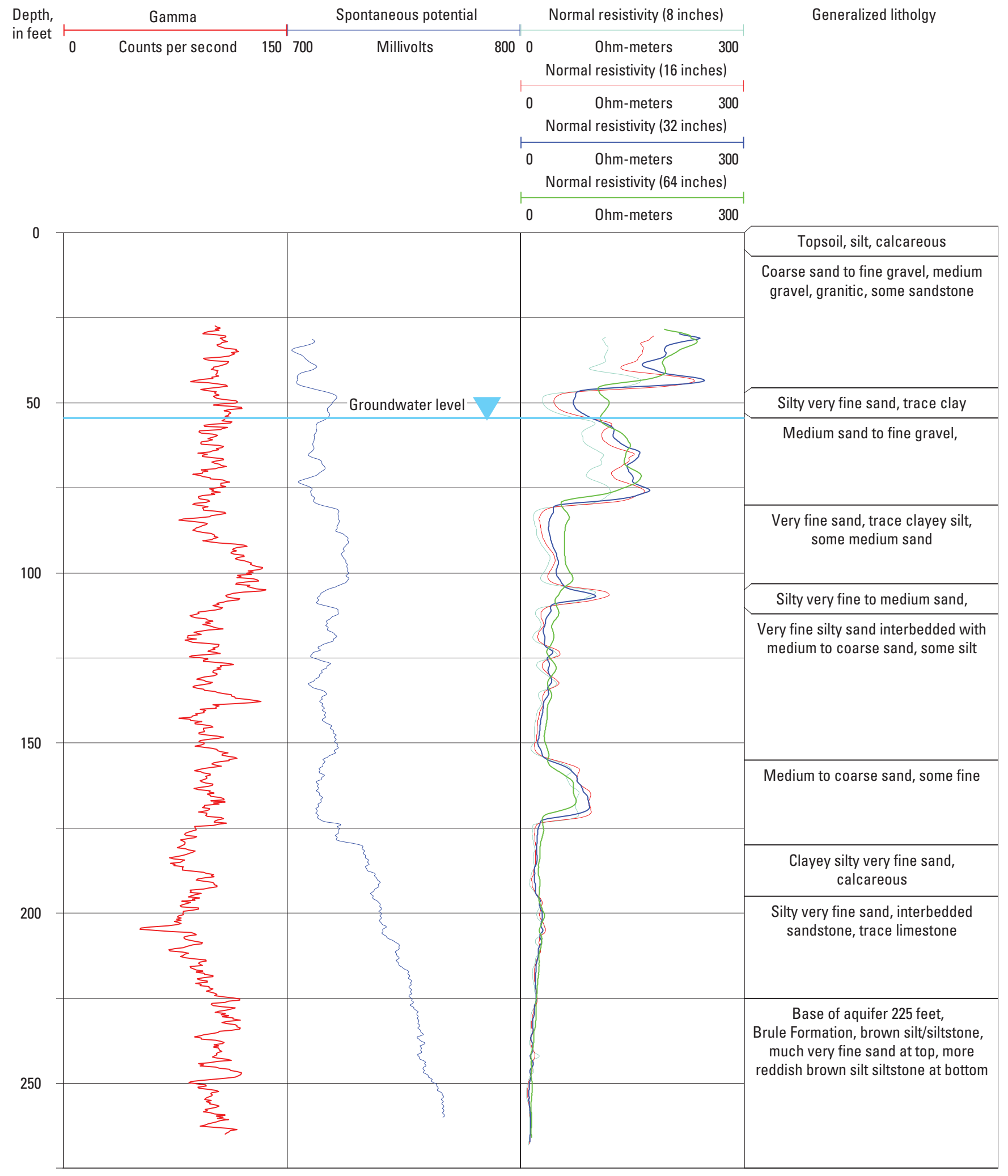

Figure 20. Composite of generalized lithologic description and geophysical logs for test hole 9-CC-11, Cheyenne County, Nebraska. 


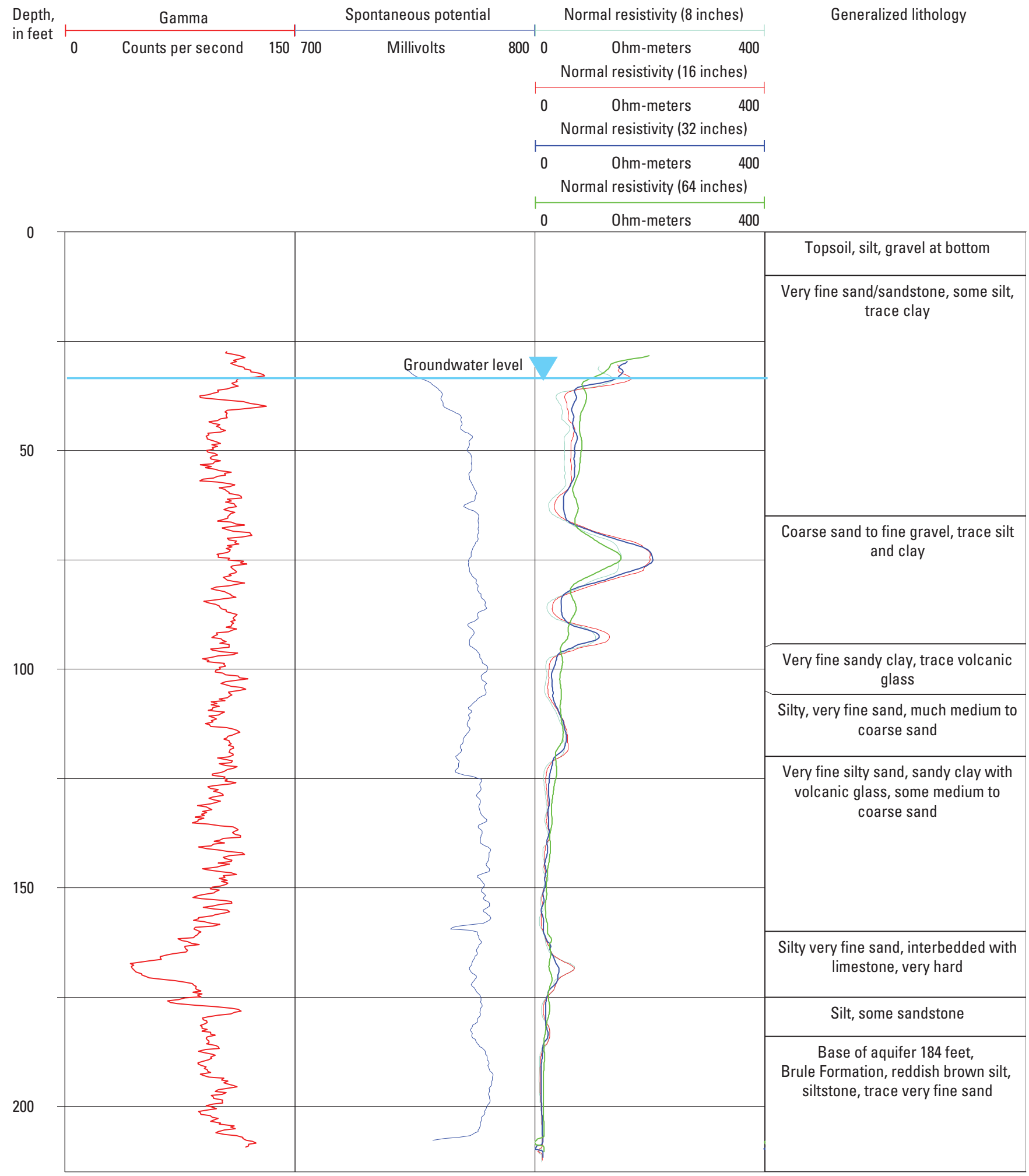

Figure 21. Composite of generalized lithologic description and geophysical logs for test hole 10-CC-11, Cheyenne County, Nebraska. 


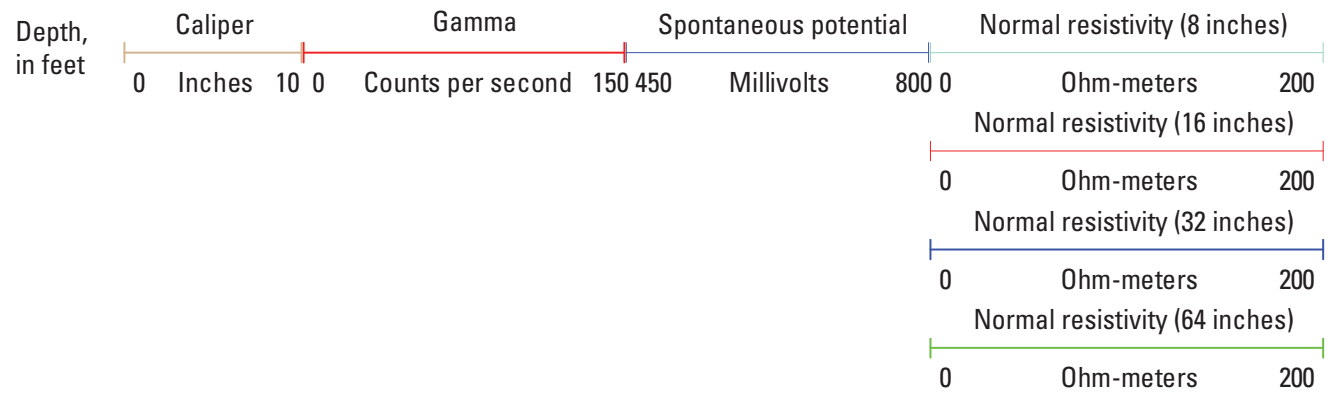

50

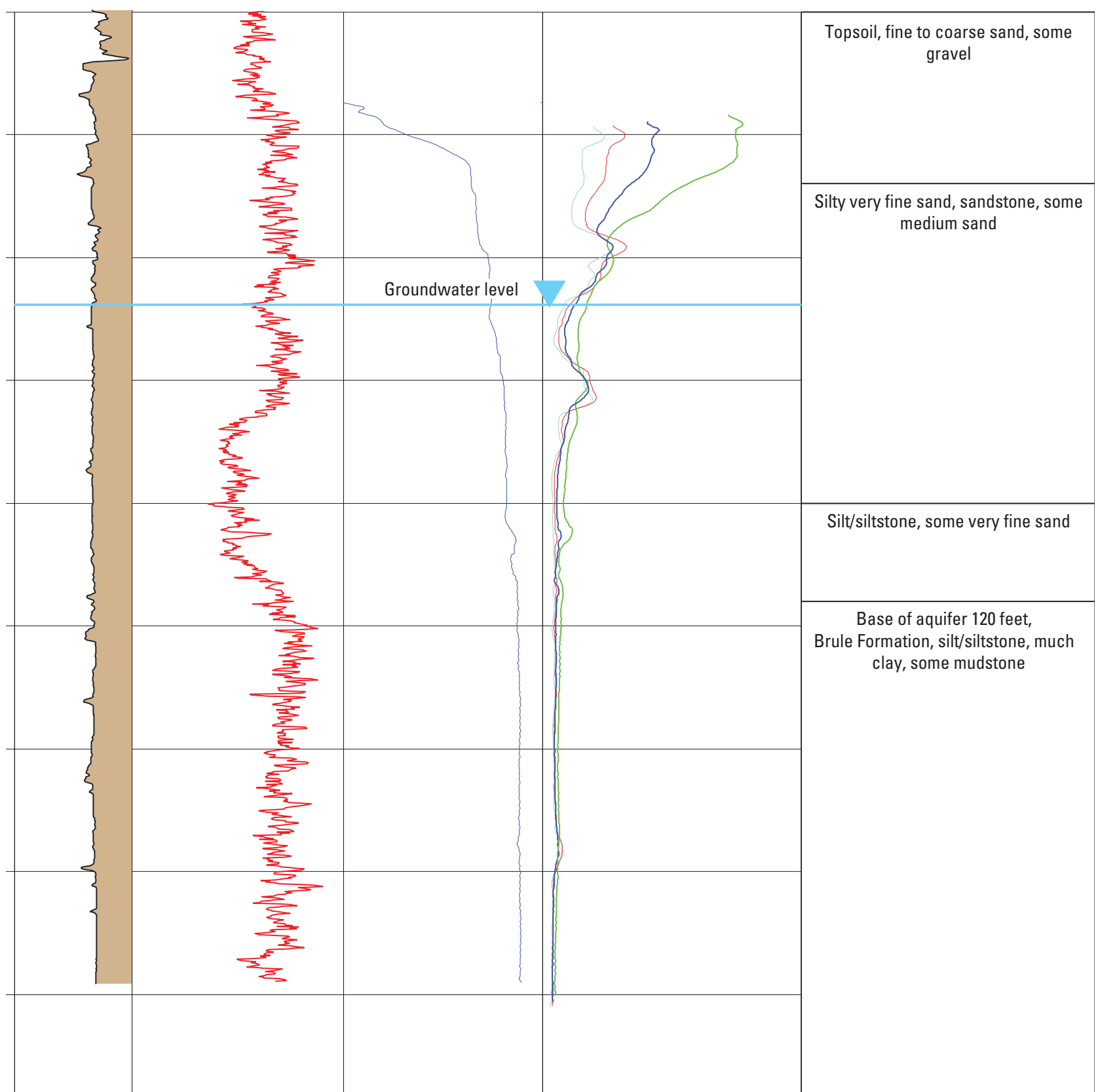

Figure 22. Composite of generalized lithologic description and geophysical logs for test hole 1-DC-12, Deuel County, Nebraska. 


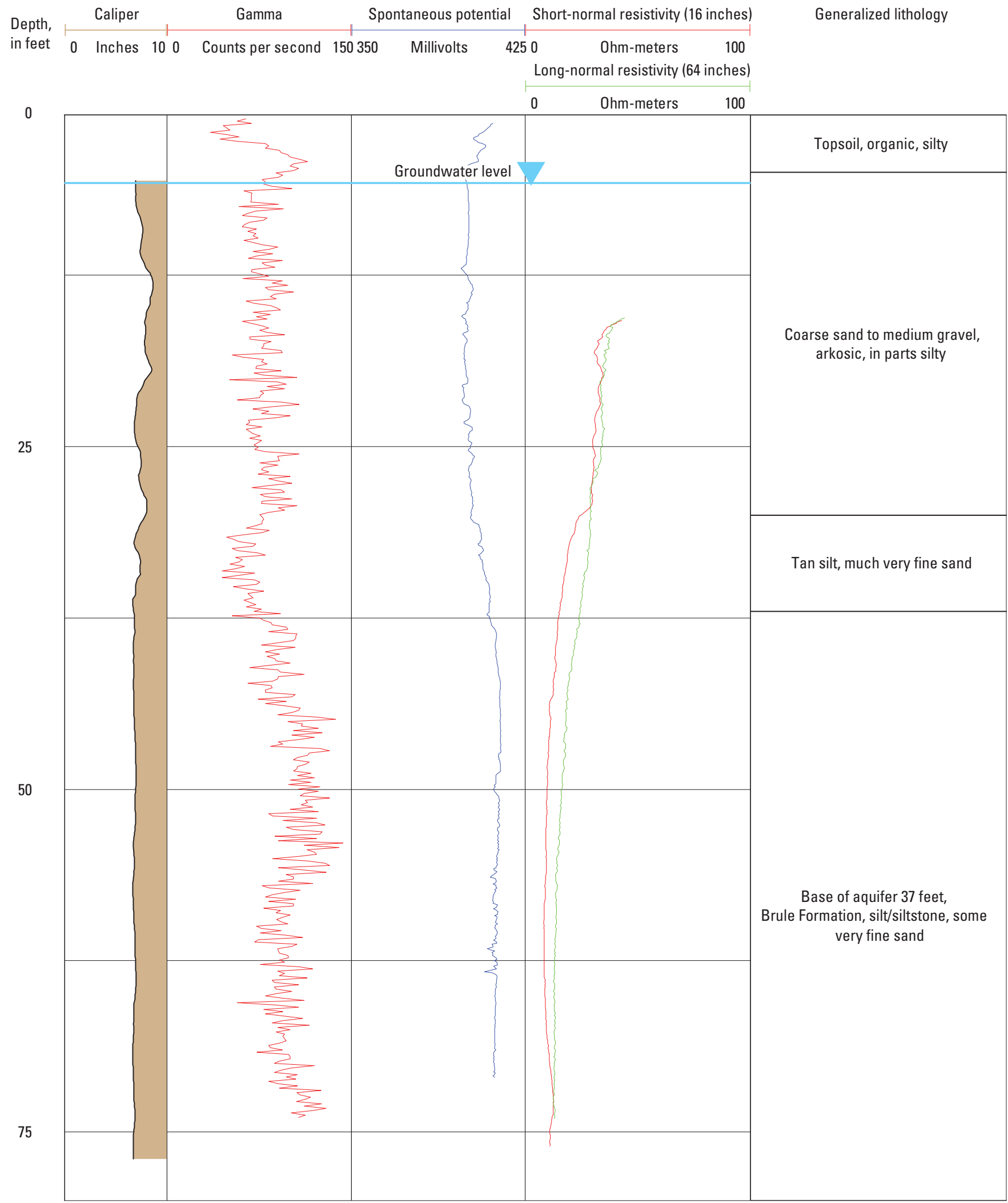

Figure 23. Composite of generalized lithologic description and geophysical logs for test hole 2-DC-12, Deuel County, Nebraska. 


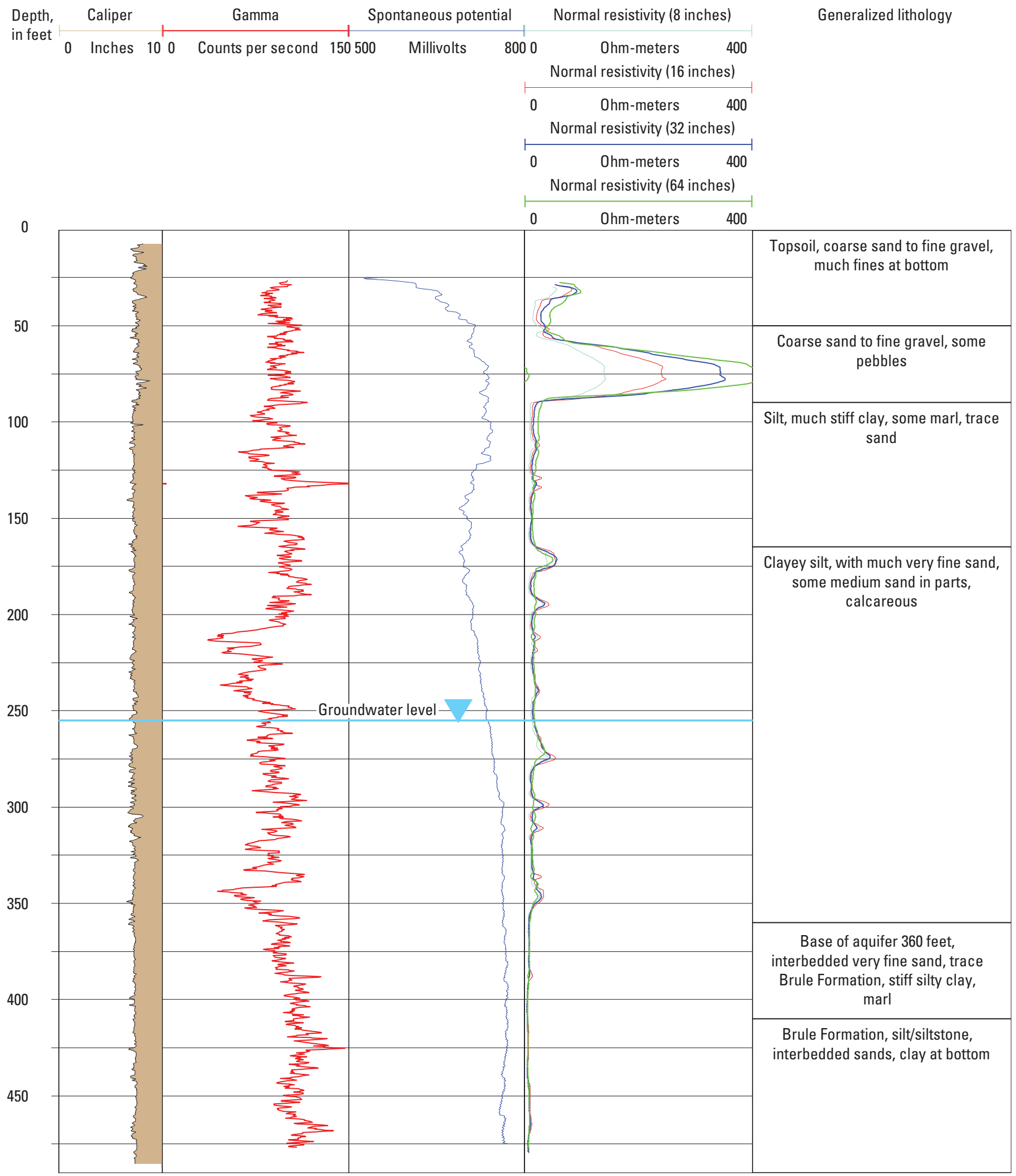

Figure 24. Composite of generalized lithologic description and geophysical logs for test hole 3-DC-12, Deuel County, Nebraska. 


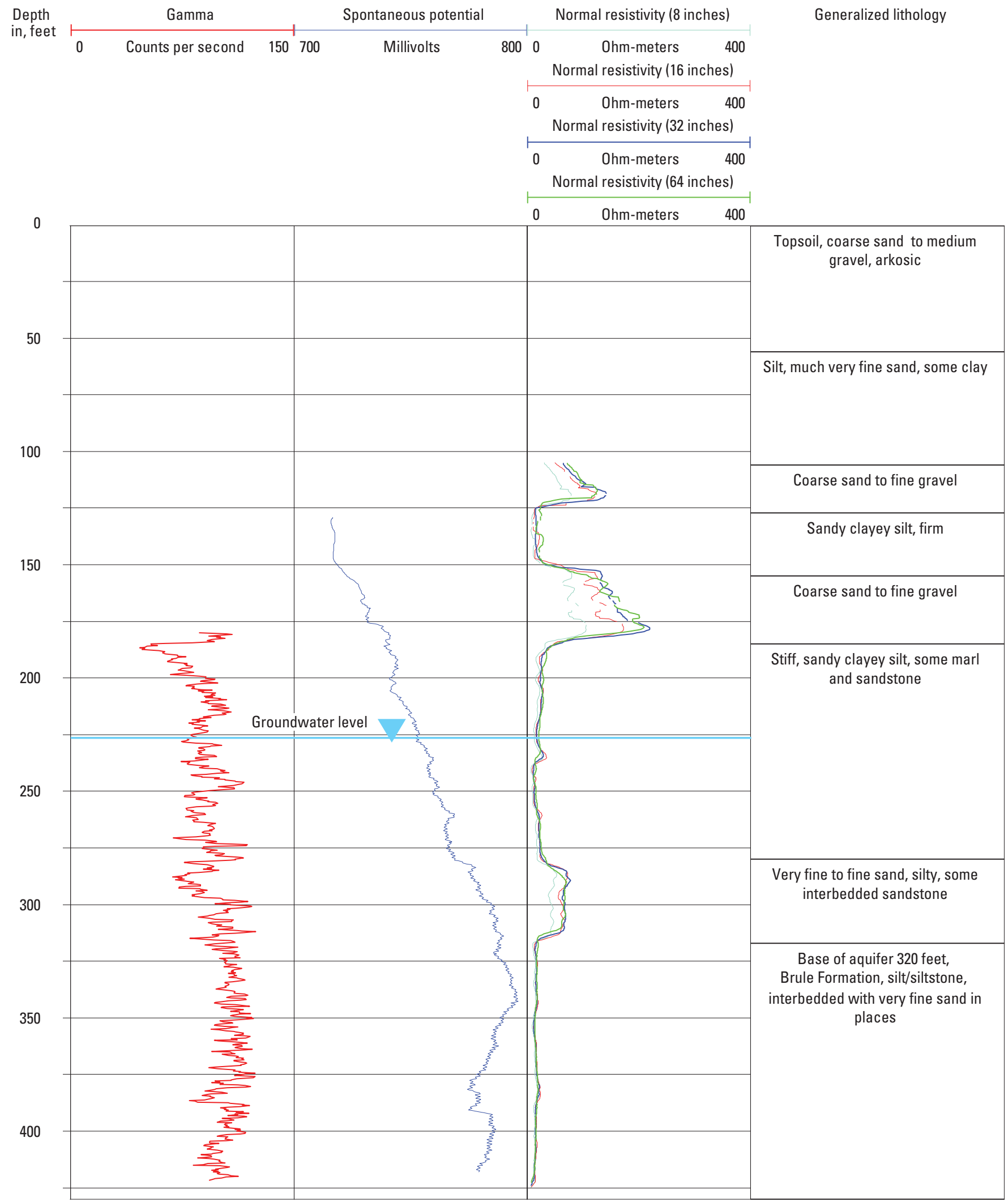

Figure 25. Composite of generalized lithologic description and geophysical logs for test hole 4-DC-12, Deuel County, Nebraska. 


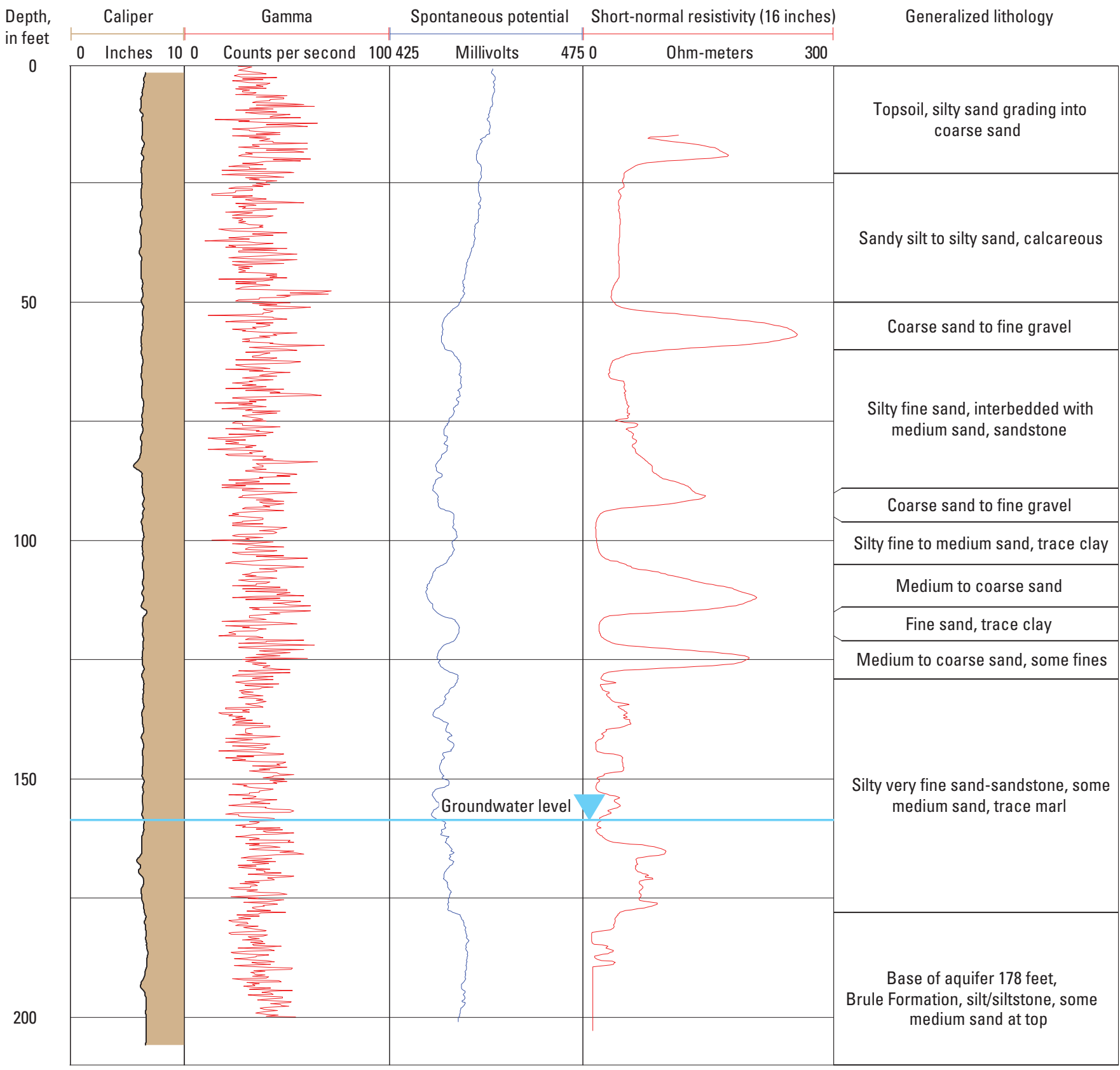

Figure 26. Composite of generalized lithologic description and geophysical logs for test hole 5-DC-12, Deuel County, Nebraska. 


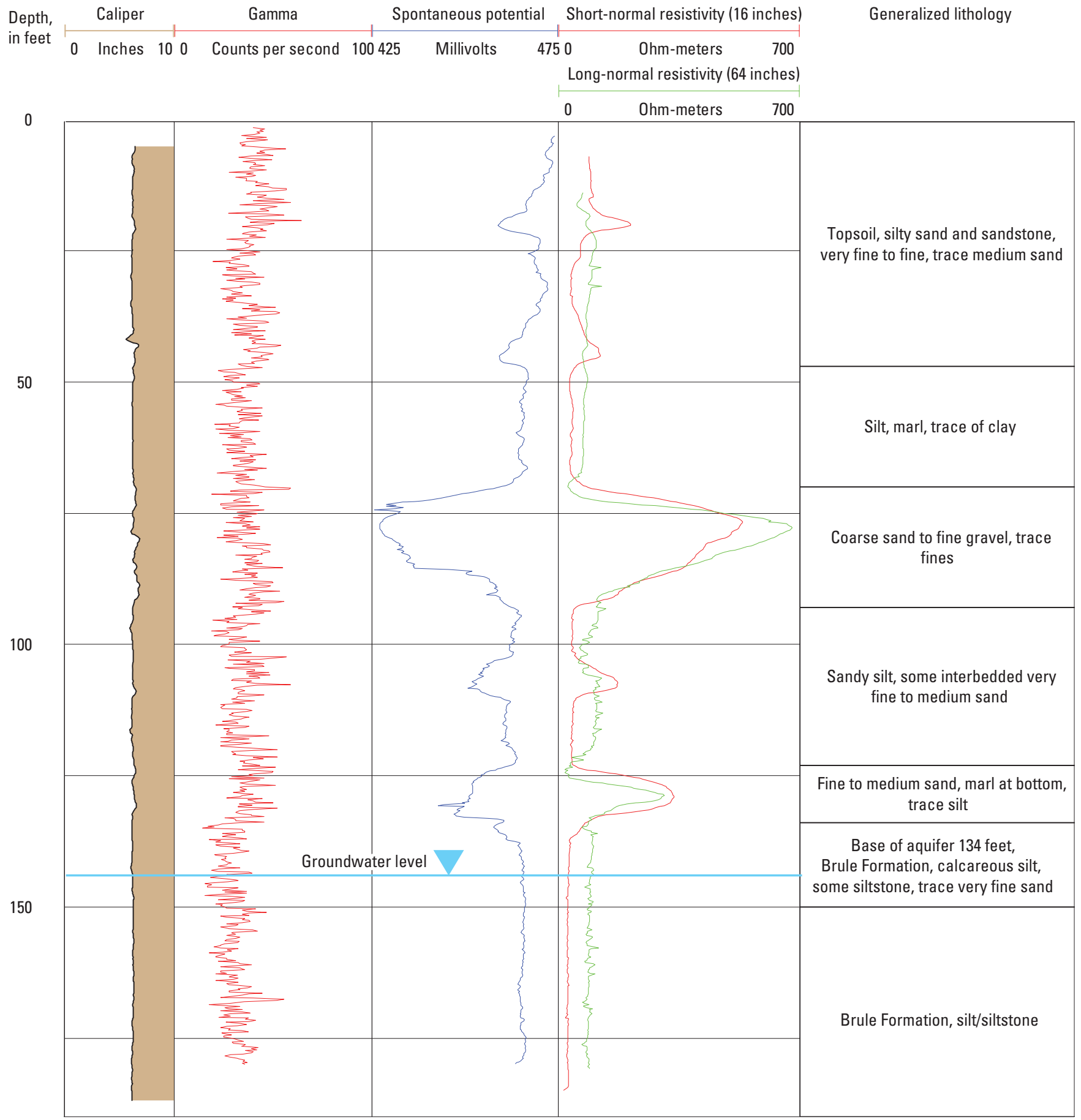

Figure 27. Composite of generalized lithologic description and geophysical logs for test hole 6-DC-12, Deuel County, Nebraska. 


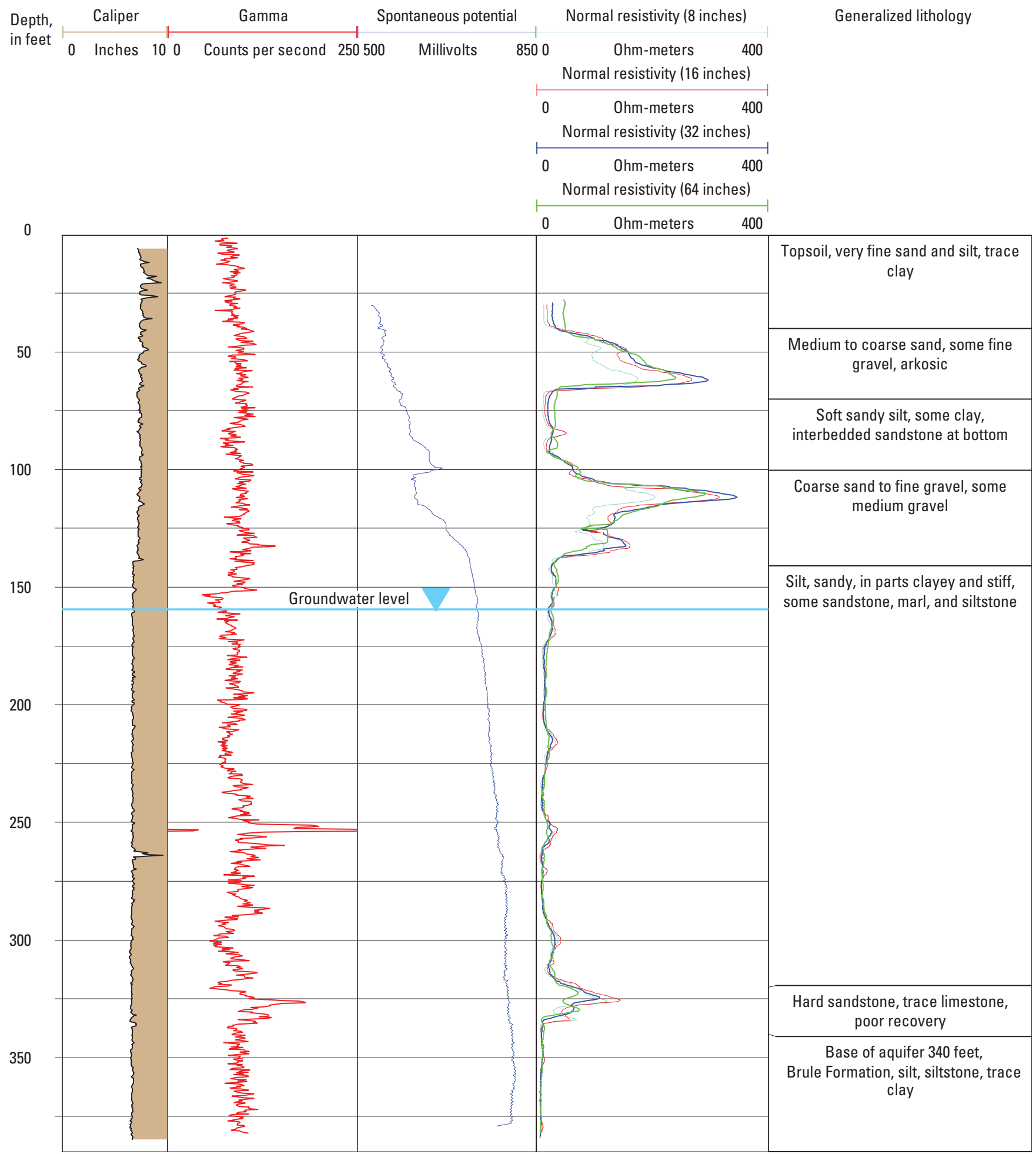

Figure 28. Composite of generalized lithologic description and geophysical logs for test hole 7-DC-12, Deuel County, Nebraska. 


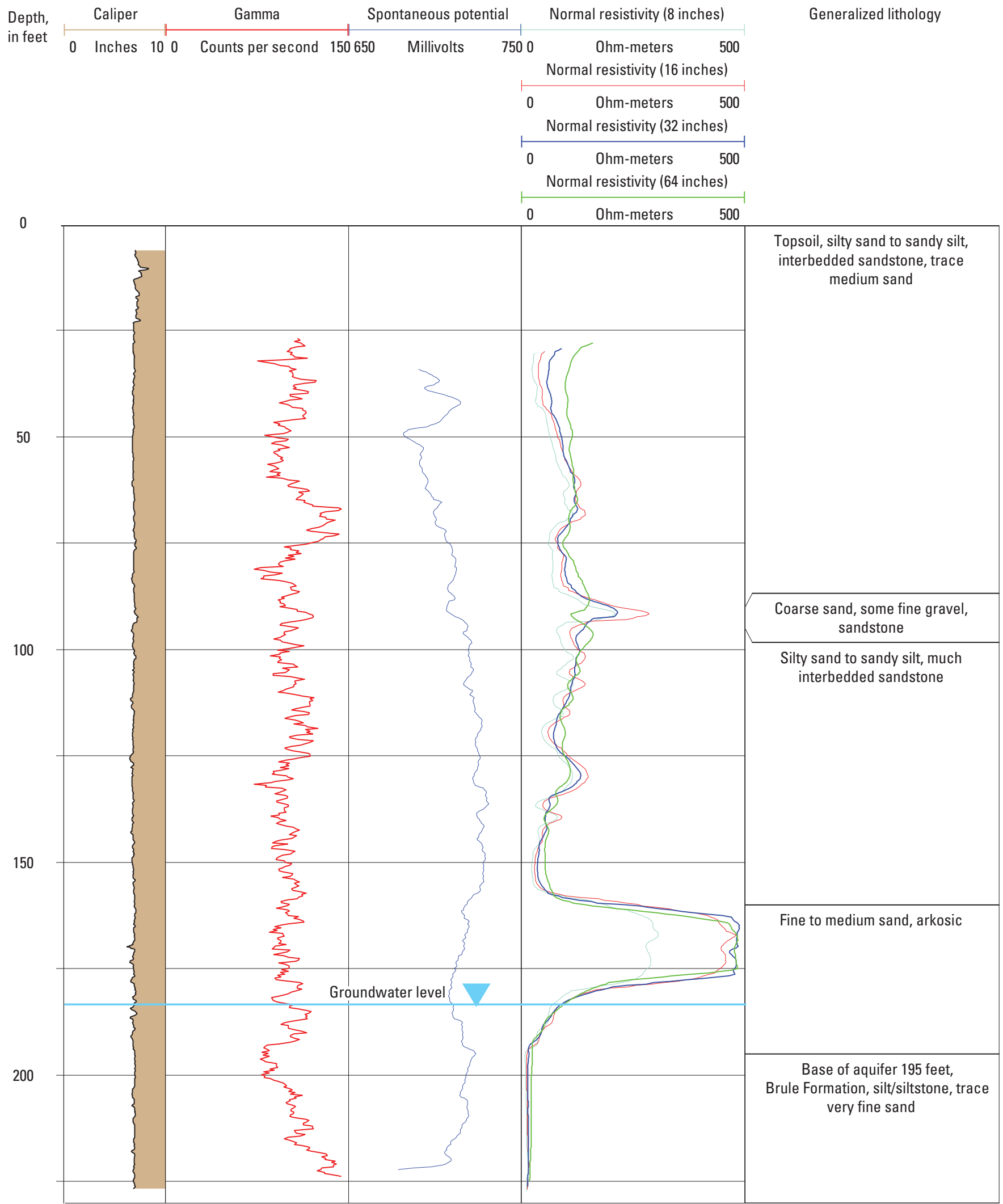

Figure 29. Composite of generalized lithologic description and geophysical logs for test hole 8-DC-12, Deuel County, Nebraska. 


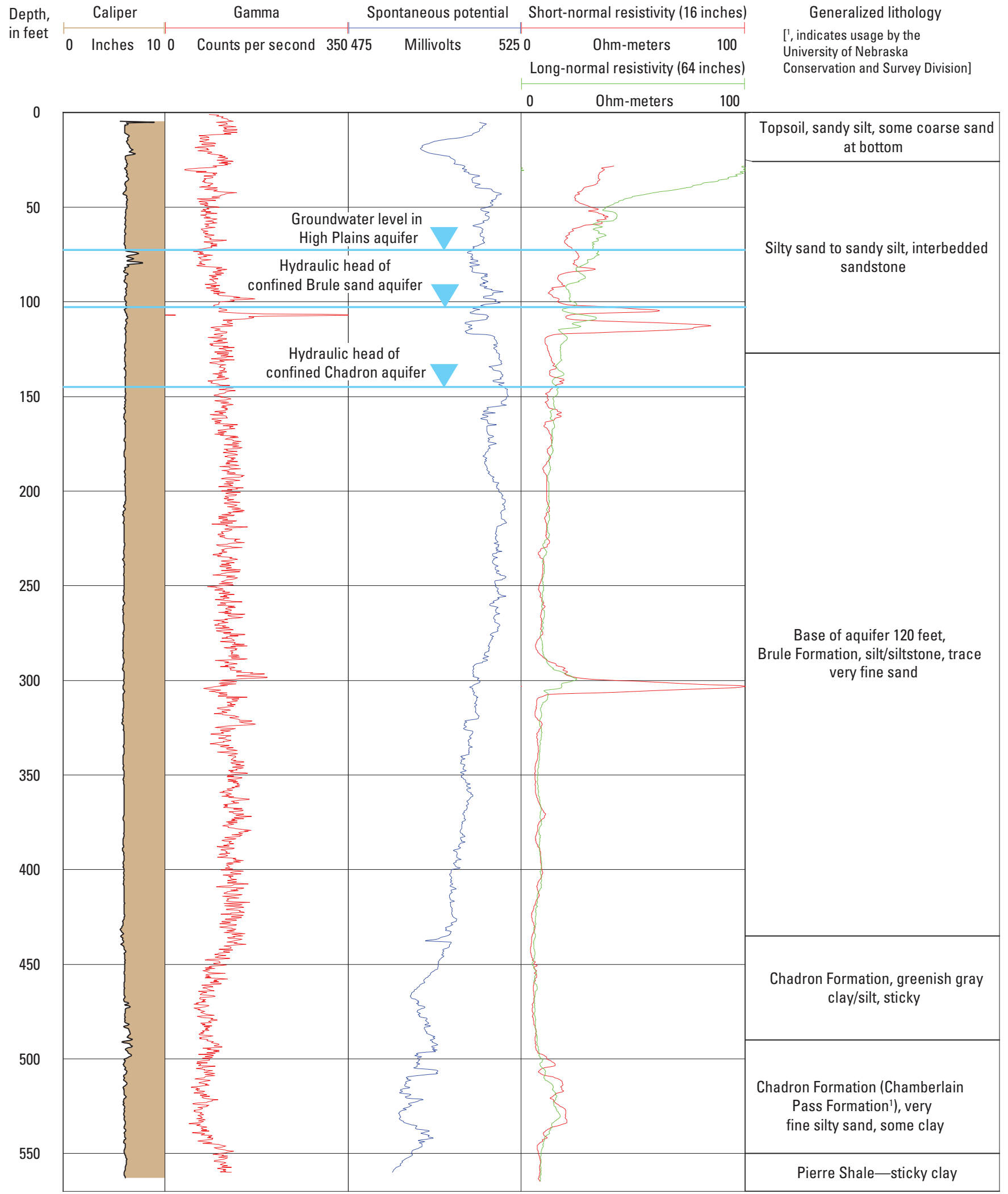

Figure 30. Composite of generalized lithologic description and geophysical logs for test hole 9-DC-12, Deuel County, Nebraska. The groundwater levels depicted were measured in the High Plains aquifer, Brule sand aquifer, and the Chadron aquifer. 
Publishing support provided by:

Rolla Publishing Service Center

For more information concerning this publication, contact:

Director, USGS Nebraska Water Science Center

5231 South 19th Street

Lincoln, Nebraska 68512

(402) 328-4100

Or visit the Nebraska Water Science Center Web site at:

http://ne.water.usgs.gov/ 



\section{$\frac{\mathbb{3}}{3}$}

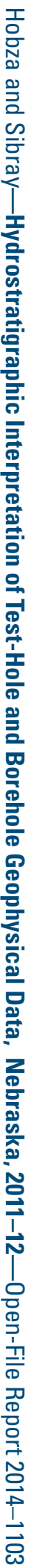

